\title{
Molecular Basis of Endometriosis and Endometrial Cancer: Current Knowledge and Future Perspectives
}

\author{
Milan Terzic ${ }^{1,2,3}$, Gulzhanat Aimagambetova ${ }^{4, *}{ }^{-}$, Jeannette Kunz ${ }^{4}\left(\mathbb{D}\right.$, Gauri Bapayeva ${ }^{2}$, Botagoz Aitbayeva ${ }^{2}$, \\ Sanja Terzic ${ }^{1}$ and Antonio Simone Laganà ${ }^{5}$ \\ 1 Department of Medicine, School of Medicine, Nazarbayev University, Kabanbay Batyr Avenue 53, \\ Nur-Sultan 010000, Kazakhstan; milan.terzic@nu.edu.kz or terzicmm@pitt.edu (M.T.); \\ sanja.terzic@nu.edu.kz (S.T.) \\ 2 National Research Center for Maternal and Child Health, Clinical Academic Department of Women's Health, \\ University Medical Center, Turan Avenue 32, Nur-Sultan 010000, Kazakhstan; \\ gauri.bapaeva@gmail.com (G.B.); aitbayeva_botagoz@inbox.ru (B.A.) \\ 3 Department of Obstetrics, Gynecology and Reproductive Sciences, University of Pittsburgh School \\ of Medicine, 300 Halket Street, Pittsburgh, PA 15213, USA \\ 4 Department of Biomedical Sciences, School of Medicine, Nazarbayev University, Kabanbay Batyr Avenue 53, \\ Nur-Sultan 010000, Kazakhstan; jeannette.kunz@nu.edu.kz \\ 5 Department of Obstetrics and Gynecology, "Filippo Del Ponte" Hospital, University of Insubria, \\ 21100 Varese, Italy; antoniosimone.lagana@uninsubria.it \\ * Correspondence: gulzhanat.aimagambetova@nu.edu.kz
}

check for updates

Citation: Terzic, M.; Aimagambetova, G.; Kunz, J.; Bapayeva, G.; Aitbayeva, B.; Terzic, S.; Laganà, A.S. Molecular Basis of Endometriosis and Endometrial Cancer: Current Knowledge and Future Perspectives. Int. J. Mol. Sci. 2021, 22, 9274. https://doi.org/ $10.3390 /$ ijms 22179274

Academic Editors: Maurizio Battino and Alfonso Baldi

Received: 22 July 2021

Accepted: 25 August 2021

Published: 27 August 2021

Publisher's Note: MDPI stays neutral with regard to jurisdictional claims in published maps and institutional affiliations.

Copyright: (c) 2021 by the authors. Licensee MDPI, Basel, Switzerland. This article is an open access article distributed under the terms and conditions of the Creative Commons Attribution (CC BY) license (https:// creativecommons.org/licenses/by/ $4.0 /)$.

\begin{abstract}
The human endometrium is a unique tissue undergoing important changes through the menstrual cycle. Under the exposure of different risk factors in a woman's lifetime, normal endometrial tissue can give rise to multiple pathologic conditions, including endometriosis and endometrial cancer. Etiology and pathophysiologic changes behind such conditions remain largely unclear. This review summarizes the current knowledge of the pathophysiology of endometriosis and its potential role in the development of endometrial cancer from a molecular perspective. A better understanding of the molecular basis of endometriosis and its role in the development of endometrial pathology will improve the approach to clinical management.
\end{abstract}

Keywords: endometriosis; endometrial cancer; ovarian cancer; molecular basis of endometriosis

\section{Morphological Features of the Human Endometrium}

The uterine endometrium is an inner mucosal layer of the uterine cavity with the unique ability to regenerate or shed depending on the phases of the menstrual cycle and hormonal levels [1,2]. The human endometrium consists of two layers: functional (stratum functionalis) and basal (stratum basalis). The endometrium undergoes structural modification and changes in specialized cells in response to fluctuations of estrogen and progesterone during the menstrual cycle [3]. The basal layer of the endometrium is responsible for the regeneration of functional layer during the proliferative phase [4-6]. A hypothesis on the regeneration process of the endometrium suggests that the functional layer quality depends on endometrial progenitors/stem cells located in the basal layer [7-9]. However, understanding of the regenerative mechanism of the endometrium during the menstrual cycle and the location of endometrial progenitor/stem cells have not been fully elucidated [10-12]. The traditional morphological theory of the endometrium describes it as two-dimensional (2D) histological structure [13-15]. However, due to the complexity of the morphology of the endometrial glands, the technical characteristics of 2D histopathological imaging have been found to be insufficient [4].

It was hypothesized that clonal genomic alterations in histologically normal endometrial glands may change the stereoscopic structure of the endometrial glands. Threedimensional (3D) pathological morphology of tissue affected by adenomyosis and 3D 
morphology of the normal endometrial glands was compared using 3D full-thickness images of the human uterine endometrium with microscopy [4]. 3D imaging revealed a more complex network of endometrial glands in human endometrium than was observed with traditional 2-dimensional (2D) imaging [4]. Using 3D imaging, Yamaguchi and co-authors (2021) found specific morphological features of human endometrial glands, including occluded glands, the plexus of the basal glands, and the gland-sharing plexus with other glands, which were not observed in the past using 2D histological methods [4]. The 3D analysis of the endometrial layers clarified that the plexus structure of the glands expanded horizontally along the muscular layer. Furthermore, these morphological features were detected regardless of age or phase of the menstrual cycle, suggesting that they are basic components of the normal human endometrium [4]. These novel findings suggest that 2D histology, which has been in use for more than 100 years, does not adequately depict the morphology of the endometrium. A clearer picture of the structure of the human could develop our understanding of various endometrial conditions and the etiology of endometriosis and endometrial cancer (EC). These diseases significantly affect reproductive age women and impact their quality of life [16-18]. Understanding the pathogenesis, immunohistochemical and molecular mechanisms of these conditions could improve the management of patients with endometriosis and EC [19-22].

\section{Endometriosis}

\subsection{Definition, Epidemiology and Classification}

Endometriosis is an estrogen-dependent inflammatory disorder of the endometrium that is characterized by the presence of functionally active endometrial tissue, stroma and glands outside the uterine cavity [21,23-26]. This condition estimated to affect up to $11 \%$ of women in reproductive age (or $\sim 200$ million women) worldwide and up to $50 \%$ of women with pelvic pain or infertility $[21,24,25,27,28]$. The etiology of endometriosis is largely unknown. Previous research has shown that endometriosis is prevalent after menarche and dramatically drops after menopause, which has led researchers to believe that the disorder is estrogen- and progesterone-dependent $[26,27,29]$.

There are different classifications of endometriosis based on staging and types (Table 1) [30]. According to the revised American Society for Reproductive Medicine (ASRM) scoring system [31,32], endometriosis is classified into four stages based on the localization and extension of the implants. The disease is classified as peritoneal, ovarian, or deep infiltrating endometriosis, which can be roughly described as the presence of endometrial tissue expanding to a depth of more than $5 \mathrm{~mm}$ below the peritoneum $[22,32,33]$. The classification includes four stages based on the severity, quantity, location, depth, and size of growths, those stages being stage I (minimal disease), stage II (mild disease), stage III (moderate disease), and stage IV (severe disease) [26,33,34]. This classification, however, has not been shown to be a reliable predictor of clinical outcomes.

As the supplement to the ASRM classification, and in order to provide a morphologically descriptive classification of deep infiltrating endometriosis, the ENZIAN classification was developed (Table 1) [30]. It takes into account retroperitoneal structures.

The Endometriosis Fertility Index (EFI) is another attempt to improve the endometriosis classification (Table 1). The EFI aims to predict pregnancy rates in patients with surgically documented endometriosis who attempt non-IVF conception. The EFI classification is a scoring system that includes assessment of factors related to a patient's history at the time of surgery, of adnexal function at conclusion of surgery, and of the extension of endometriosis [30]. 
Table 1. Classification of endometriosis.

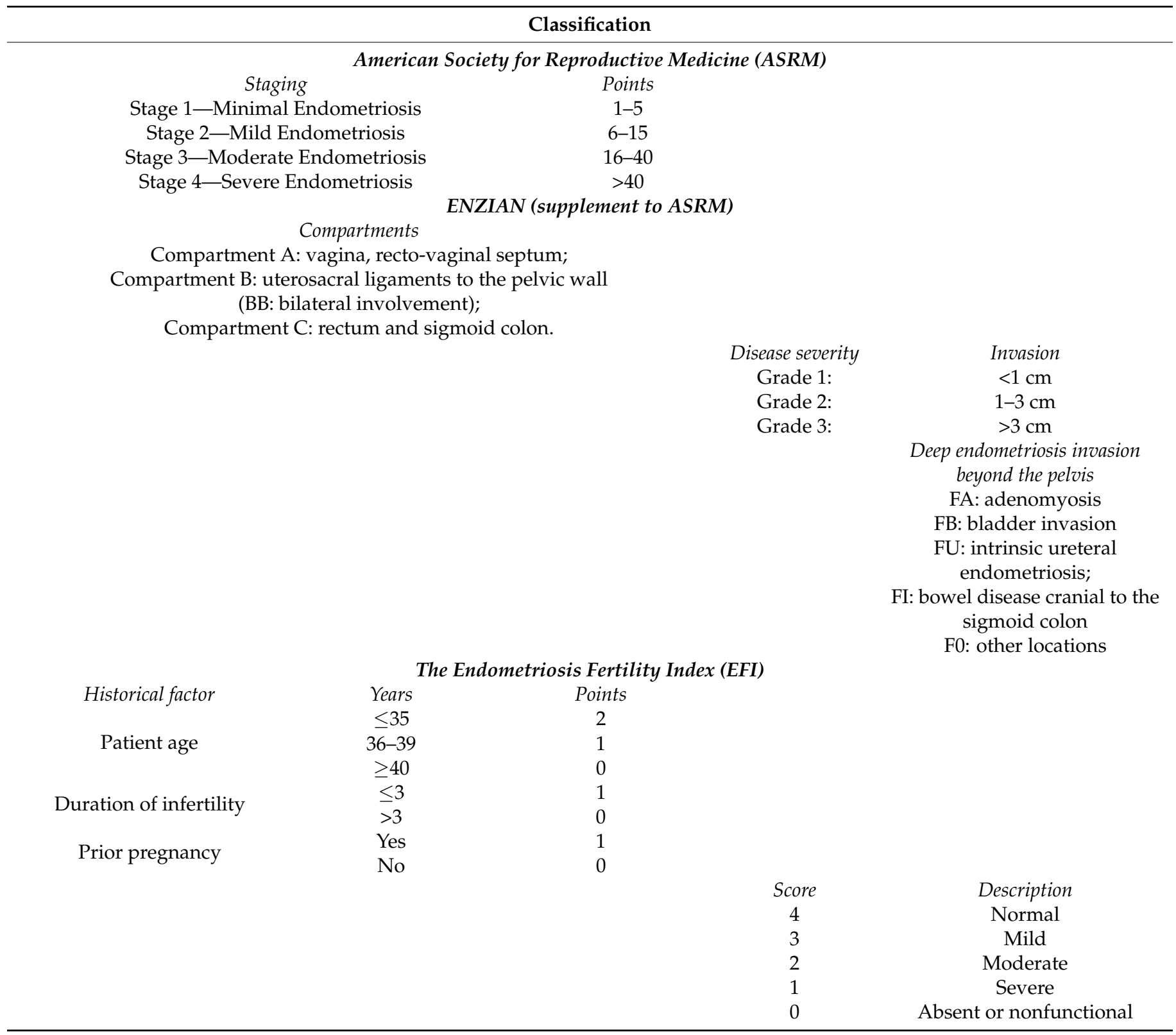

Following another classification, endometriosis is subdivided into three types: superficial peritoneal disease, ovarian endometrioma, and deep endometriotic lesions [35,36]. Adenomyosis, as "internal" uterine endometriosis, is characterized by the presence of endometrial glands and stromas within the myometrium that causes myometrial inflammation and hypertrophy $[35,37,38]$. Adenomyosis can be classified in several different subtypes: (a) intrinsic adenomyosis, (b) extrinsic adenomyosis, (c) adenomyosis externa, and (d) focal adenomyosis located in the outer myometrium [35,37,38]. Although there are many studies supporting this new classification, international consensus has not yet been achieved [35].

A major disadvantage of all existing classifications is that no one of them links the severity of the pain with the findings (imaging, laparoscopic) [39]. Some patients who are classified as "severe" by ASRM experience little pain but have associated infertility. Others, with only superficial red and blue lesions and minor adhesions, may experience severe pain and consequently a low quality of life [39-41]. 
Abrao and Miller recently proposed a new classification system [42]. They propose that a classification should (1) clearly describe the sites and extent of disease; (2) provide a close correlation with the symptoms of endometriosis; (3) reflect the surgical difficulty encountered relative to the disease location; (4) be user-friendly with tools that are conducive to support a surgeon's busy practice by enabling completion of documentation immediately upon procedure conclusion; (5) be validated for both pain and infertility; (6) create a comprehensive universal language that is meaningful for clinical practitioners and researchers [39,42].

\subsection{Risk Factors of Endometriosis}

A number of modifiable and non-modifiable risk factors have been reported to be both positively and negatively associated with the development of endometriosis (Figure 1) $[27,28,43,44]$. Non-modifiable risk factors known to be associated with endometriosis are the following: genetic, endocrine, immunological, and ethnicity [21,45]. There are also modifiable factors, the effect of which could be decreased substantially by lifestyle changes. Those factors are microbiotic, environmental factors (exposure to endocrine-disrupting chemicals), alcohol/caffeine intake, smoking, and physical activity [27]. Those factors may influence estrogen levels and contribute to the development of endometriosis [27].

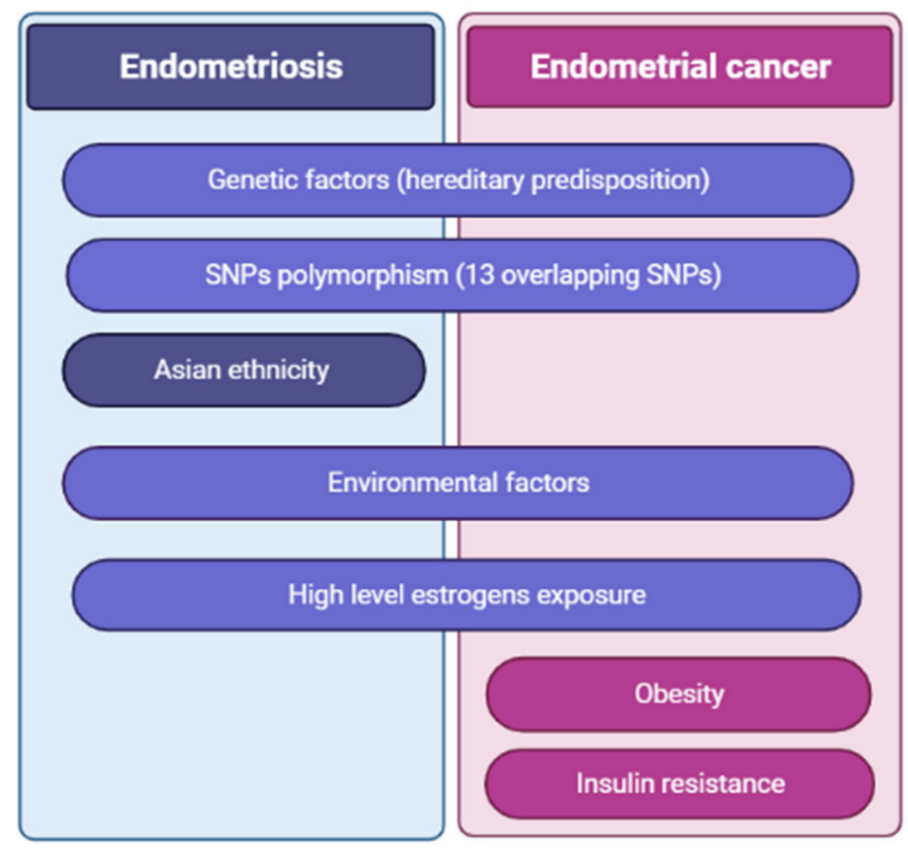

Figure 1. Risk factors for endometriosis and endometrial cancer. Created at BioRender.com (accessed on 15 July 2021).

The risk of endometriosis has been strongly linked to ethnicity. Many researchers have reported a nine-fold increase in risk of endometriosis development among women of Asian ethnicity if compared with the European-American Caucasian female population $[27,43,46]$. Among other factors, prolonged estrogen exposure (e.g., early age at menarche, shorter menstrual cycles, nulliparity) [47], low body mass index, and uterine outlet obstruction [48] have been suggested as predisposing to endometriosis.

It is well known that endometriosis has a strong genetic predisposition [25,43]. The evidence for an association between genetic polymorphisms and risk of endometriosis is robust [43]. Together with the strong link to hereditary factors, development of endometriosis is also affected by environmental exposures [26]. Environmental factors such as elevated levels of phthalate esters, persistent organochlorine pollutants, perfluorochemicals, and exposure to cigarette smoke can increase risk of developing endometriosis by inducing 
oxidative stress, altering hormonal homeostasis, or by changing immune responses [43]. Maternal exposure to diethylstilbestrol (DES) has been associated with a greater risk of endometriosis in female offspring [28].

Modifiable risk factors such as caffeine intake have been hypothesized to be influential in the pathology of gynecological disease due to its ability to influence estradiol levels [27,49]. Much like caffeine, alcohol intake and tobacco smoking are hypothesized to alter reproductive hormones due to the activation of aromatases leading to increased conversion of testosterone to estrogens [27]. Moreover, tobacco smoking may also increase the inflammatory response. Physical activity has been shown to reduce the risk of developing many gynecological diseases $[27,50]$. Other risk factors, such as the presence of lower genital tract infections, have also been proposed as risk factors. [43,51].

Some genetic factors have been found to serve as risk factors for endometriosis. Genome-wide association studies have, to date, identified 19 independent single-nucleotide polymorphisms (SNPs) as being significantly associated with endometriosis [52]. Moreover, the authors found a significant genetic overlap between endometriosis and EC in a genetic correlation analysis, which found 13 SNPs that appeared to be involved in development of both conditions [52].

\subsection{Pathophysiology of Endometriosis}

To date, the etiology and pathogenesis of endometriosis remains controversial. Multiple theories have been proposed to explain the pathogenesis of endometriosis $[24,25,38]$. Among the most recognized and reasonable are retrograde menstrual blood flow, coelomic metaplasia, and Müllerian remnants theories [21,24,39,53,54]. Amongst the various hypotheses, the one that has the greatest consensus is Sampsons' retrograde menstruation. Retrograde menstruation is the process in which endometrial cells and fragments of the tissue shed during menstrual bleeding and are transported into the peritoneal cavity due to the retroperistaltic movements of the fallopian tubes $[21,24,53]$. Implantation of these particles and subsequent proliferation during the menstrual cycle leads to the damage of pelvic organs at positions of implantation [21]. However, the hypothesis about the retrograde menstruation as a potential cause of endometriosis does not explain localization of endometrial tissue that can be found in rare cases of extragonadal endometriosis and endometriosis in male patients [26]. Another theory suggests that endometriosis develops due to endometrial cells transferred through the lymphatic system to other parts of the body, where they further grow and proliferate $[21,24,26]$. Additionally, it has been proposed that circulating blood cells originating from bone marrow differentiate into endometriotic tissue at various body sites [24,55]. Distant organ endometriosis, such as lung and brain endometriosis, is very rarely described and might be explained by vascular spread $[21,24]$.

Meyer's hypothesis about coelomic metaplasia suggests development of endometriosis from the visceral epithelium, which can be converted to endometrial tissue by metaplastic processes [21,39].

More recent studies suggest that endometriosis is a pelvic inflammatory condition, so called "peritonitis without germs" [39,53]. This is based on the fact that the peritoneal fluid has an increased concentration of activated macrophages and an inflammatory profile in the cytokine/chemokine axis [39,56]. Cousins and Gargett in 2018 proposed that the human endometrium regenerates cyclically every month mediated by endometrial stem/progenitor cells such as CD140b+, CD146+, or SUSD2+ endometrial mesenchymal stem cells (eMSCs) [57]. N-cadherin + endometrial epithelial progenitor cells and side population cells may also contribute to the pathogenesis of the disease. They hypothesized that the eMSCs may have a role in the generation of progesterone-resistant phenotype endometrial stromal fibroblasts $[39,57]$. According to the other recent theories, deregulation of genes and the Wingless-related integration site (Wnt)/ $\beta$-catenin signaling pathway would produce an aberration and the axial extension of the identity of the anterior-posterior patterning, whilst a deregulation of Hox genes and cofactor pre-B-cell leukemia homeobox 1 (Pbx1) produces an aberration in the segmentation of the mesoderm [21]. This 
may cause aberrant placement of stem cells with endometrial phenotype and maintain them in a quiescent niche. Transcriptional activity induces the expression of vascular endothelial growth factor (VEGF) that stimulates the vascular endothelial cell. On the other hand, Müllerian inhibiting factor (MIF) induces endometrial cell mitosis, whose survival is supported by the activation of antiapoptotic gene B-cell lymphoma 2 (Bcl-2), by the degradation of the extracellular matrix by matrix metalloproteinases (MMPs) via intercellular adhesion molecule 1 (ICAM-1) and vascular cell adhesion protein 1 (VCAM-1), creating the conditions for differentiation, adhesion, proliferation, and survival of ectopic endometrial cells [21]. This will lead to decreased apoptosis of ectopic endometrial-like cells [58-60], which escape from immune surveillance, and subsequently implant and proliferate. According to a recent review by Patel and colleagues, there is growing evidence that hormonal and immune factors create a pro-inflammatory microenvironment that support the persistence of endometriosis [61]. It is clear there is still much to learn about the nature and pathophysiology of endometriosis, and development of these theories could contribute to a greater understanding of the disease.

\subsection{Clinical Presentation and Diagnostic Tools}

Endometriosis is difficult to diagnose for many reasons: lack of clear understanding of etiologic factors, diversity of hypotheses for pathogenesis, different clinical presentation of the disease, and existence of asymptomatic cases [62]. Careful patient interview including family history, detailed examination, and additional imaging work-up are required for diagnosis [63,64].

Most women diagnosed with endometriosis present with multiple diverse symptoms [25]. Commonly reported complaints include chronic pelvic pain, dysmenorrhea, dyspareunia, dyschezia, and infertility/subfertility [25,33,39].

Chronic pelvic pain accounts for $10 \%$ of outpatient gynecologic visits, while local pain or tenderness on pelvic examination is associated with pelvic disease in $97 \%$ of patients and with endometriosis in $66 \%$ of patients [65]. Dysmenorrhea and general pelvic pain are common symptoms of endometriosis, regardless of age at diagnosis [66]. Pelvic pain due to endometriosis is usually chronic (lasting $\geq 6$ months) and is associated with dysmenorrhea (in 50 to $90 \%$ of cases), dyspareunia, deep pelvic pain, and lower abdominal pain with or without back and loin pain [65]. Most women experience pain of different severity: from mild or moderate pain (pain usually requiring medication) to severe pain (pain requiring medications and bed rest) during menses over the lifetime [66]. Pain in endometriosis has a complex mechanism. Increased systemic and local proinflammatory cytokines and growth factors due to the chronic inflammation in endometriosis contribute to the mechanism of chronic pain development through persistent noxious stimulation, chronic inflammation, and nerve injury, which will alter pain processing and result in central sensitization $[25,62]$. Surgical treatment in many cases increases central sensitization, and patients often report worsening of symptoms after surgery $[25,67]$. The severity of pain is often associated with the depth of endometriotic infiltration rather than the size of the lesion or cyst $[25,62,68]$. Dyspareunia is another common symptom that is closely related to pain and nerve sensitization [25].

Some patients may experience gastrointestinal (nausea and vomiting, more frequent bowel movements accompanying pelvic pain) and urinary (frequent urination when experiencing menstrual pain) symptoms $[65,66]$.

Infertility and subfertility are other important issues related to endometriosis. In cases of severe and deep infiltrating endometriosis [22,33,69], the mechanism of infertility is the alteration of normal anatomy of the reproductive organs [25]. However, in cases of a small ectopic endometrial implants/lesions, the mechanism of infertility is not clear yet. The authors suggested an endometrial defect as the explanation of implantation impairment in endometriosis. This hypothesis is supported by numerous studies showing decreased expression of several biomarkers of implantation [25,69]. 
Following the key steps during the initial clinical examination in the diagnosis of women with endometriosis, imaging investigations should be done in order to confirm the condition. Some biological tests invented currently have little or no merit in the diagnosis of endometriosis, and no biomarker tests have been identified to be conclusive $[26,62,70,71]$. In contrast, imaging techniques led to substantial improvements in the diagnosis of endometriosis [25,62,72]. The most helpful tools are transvaginal ultrasound (TVUS) [73,74] and MRI [62,72]. In addition, sigmoid, ileocecal, and urological lesions can be detected with supplementary radiological techniques such as transrectal sonography (TRS), rectal endoscopic sonography (RES) [75,76], multidetector CT scan with retrograde colonic opacification and late urography, and/or uro-MRI [62,77]. However, a recent Cochrane meta-analysis reported inconclusive data from TRS and RES studies [77]. If using these methods, it is important to remember that TRS ( $5 \mathrm{MHz}$ frequency) enables a limited analysis of the rectosigmoid colon, whereas RES (7.5-12 MHz) provides an overview of the whole sigmoid and rectosigmoid colon with higher spatial resolution [72].

\section{Endometrial Cancer}

\subsection{Definition, Epidemiology and Classification}

Endometrial cancer is a malignant disease of the inner layer of the uterus (endometrium) $[3,78]$. It is one of the most common gynecological malignant tumors in developed countries [3,78-80]. In 2012, 527,600 women worldwide were diagnosed with EC, and the mortality rate was 1.7 to 2.4 per 100,000 women [81]. According to the American Cancer Society (ACS), in 2021, there will be an estimated 66,570 new cases of the uterine body cancer diagnosed in the United States and more than 12,940 deaths [82]. These calculations include both EC and uterine sarcomas. Up to $10 \%$ of uterine body cancers are sarcomas, so the actual numbers for EC cases and deaths are slightly lower than these estimates [82].

Nowadays, worldwide, EC is the seventh most common malignant disorder, but incidence varies among regions [3]. In less developed countries, risk factors are less common and EC is rare, although specific mortality is higher. Uterine corpus cancer is the 6th leading cause of cancer death among women in the United States and the 8th leading cause of cancer-related death amongst European women [83]. The incidence is ten times higher in North America and Europe than in less developed countries; in these regions, this cancer is the most common of the female genital organs and the 4th most common site after breast, lung, and colorectal cancers $[3,83]$.

During the past two decades, the incidence and mortality rate for EC has increased by more than $100 \%[80,84,85]$. Moreover, the incidence varies $\sim 10$-fold worldwide, with estimated age-standardized rates of 15 per 100,000 women and higher in 2018 in Europe and North America (developed countries) [84,85].

EC affects mainly post-menopausal women [86]. The average age of women diagnosed with EC is 60. It is uncommon in women under the age of 45 [82].

ECs are classified into various histological subtypes, including endometrioid EC, serous EC, clear-cell EC, mixed EC, and uterine carcinosarcoma (UCS), which differ in their frequency, clinical presentation, prognosis, and associated epidemiological risk factors [82,83].

Most EC are adenocarcinomas, and endometrioid cancer is the most common type of adenocarcinoma [82]. Endometrioid cancers arise from the glandular cells of the endometrium, and they look like the normal endometrium. There are many variants (or sub-types) of endometrioid cancers including adenocarcinoma (with squamous differentiation), adenoacanthoma, adenosquamous (or mixed cell), secretory carcinoma, ciliated carcinoma, and villoglandular adenocarcinoma [82].

Endometrioid ECs constitute more than $80 \%$ of newly diagnosed EC cases [83]. These cancers with its subtypes are generally estrogen-dependent and have a mean age at diagnosis of 62 years [83]. In contrast, serous ECs and clear-cell ECs are relatively uncommon, accounting for $\sim 10 \%$ and $3 \%$ of newly diagnosed ECs, are generally estrogen-independent, and are diagnosed later in life (mean of 66.5 and 65.6 years, respectively) [82,83]. 
The prognosis for most newly diagnosed EC patients is good, with a relative 5-year survival rate of $81.1 \%$ (2008-2014) [83,87]. The generally high survival rate for EC is largely driven by the frequent early detection of endometrioid ECs, coupled with the effectiveness of surgery for treating many early-stage, low-grade EECs.

\subsection{Risk and Protective Factors of Endometrial Cancer}

Multiple genetic (non-modifiable) and non-genetic (modifiable) risk factors have been associated with the development of EC (Figure 1) [78,88,89]. Genome-wide association studies have found nine independent SNPs being significantly associated with EC [52].

Race is a non-modifiable, genetic factor that plays an important role in the development of EC, as rates are highest in North America and northern Europe, lower in eastern Europe and Latin America, and the lowest in Asia and Africa [79,84,90]. Age is another non-modifiable risk factor. It is well-documented that EC primarily affects postmenopausal women, with the average age of 60 at the time of diagnosis [90]. The peak age-specific incidence is from 75 to 79 years, with $85 \%$ of cases occurring after the age of 50 and only $5 \%$ before the age of 40 [90]. Young, premenopausal women diagnosed with EC usually have other factors, contributing to the risk of the disease.

Several non-genetic risk factors are linked with an increased risk of EC, particularly for the most prevalent histological subtype of endometrioid EC [78]. These include obesity, physical inactivity, excess of endogenous estrogens, insulin resistance, and polycystic ovary syndrome $[3,78,79,84,88]$. In addition, conditions involving excess of exogenous estrogens due to hormone replacement with unopposed estrogen (i.e., estrogen therapy without progesterone) predispose women to endometrial cancer [88,90].

Tamoxifen (selective estrogen receptor modulator (SERM)) used for breast cancer treatment approximately doubles the risk of both endometrioid and non-endometrioid types of EC if administered for 5 years and longer $[78,88]$. The mechanism behind is antiestrogenic effects in the breast and proestrogenic effects in the uterus $[88,91]$.

The recent systematic review studying risk factors of EC concluded the presence of strong evidence associating increased body mass index (BMI) and obesity with the risk of EC development $[78,85,90,92]$. According to the US statistics, $57 \%$ of all ECs are attributable to obesity $[76,80,86]$. In the United Kingdom (UK) almost half of all ECs are attributed to overweight (BMI $\geq 25 \mathrm{~kg} / \mathrm{m}^{2}$ ) and obesity (BMI $\geq 30 \mathrm{~kg} / \mathrm{m}^{2}$ ) [93]. If compared with all other cancers, EC has the strongest association with obesity $[78,88,93]$. Women with a normal BMI have a much lower lifetime risk of EC (up to 3\%), but for every 5-unit increase in BMI, the risk of EC increases by more than $50 \%[88,93,94]$. Although the average age at diagnosis is 63 years, EC incidence is increasing among young obese women [88]. Specific lipid metabolites, including phospholipids and sphingolipids (sphingomyelins), demonstrated good accuracy for the detection of EC [93]. The underling mechanisms of the association of obesity with EC are not fully understood; however, they likely include higher estrogen levels in postmenopausal women due to aromatase activity and adipose tissue conversion of androgens into estrogens, hyperinsulinemia, and chronic inflammation $[78,95,96]$.

As a condition closely associated with insulin resistance and obesity, highly suggestive evidence that diabetes mellitus increases the risk of EC was reported in recent systematic reviews $[78,97]$. Hyperinsulinemia, which is a common phenomenon prior to diabetes onset, likely has a causal association with EC through direct mitogenic effects or by increasing the levels of bioavailable estrogen through a reduction in sex hormone binding globulin levels $[78,98]$.

However, there are some factors that have protective effect against EC $[3,78,88]$. Those factors include parity (with an inverse association between parity and the risk of endometrial cancer) and oral contraceptive pills [88]. The recent systematic review studying risk factors of EC found strong evidence for a $40 \%$ reduction in endometrial cancer incidence among parous compared to nulliparous women [78]. Hormonal changes during pregnancy 
may explain this association, usually featured by increased progesterone production with protective effects on the endometrium [78].

Oral contraceptive use reduces the risk of endometrial cancer up to $40 \%$. Moreover, the longer the administration, the stronger the protective effect, which can persist even decades after cessation $[88,99]$. Additionally, coffee consumption has been shown to be inversely associated with EC $[78,100,101]$.

Some researchers reported evidence that smoking reduced the risk of EC in cohort studies, although the evidence became strong when case-control studies were included $[78,101]$. The majority of the published cohort studies showed a reduction in risk of endometrial cancer among current or former smokers compared to never smokers [78,92,102,103]. A mechanism behind the link between decreased incidence of EC and smoking is the possible anti-estrogenic effect of nicotine; however, it has limited direct evidence and requires further investigations [78].

\subsection{Pathophysiology of Endometrial Cancer}

Based on epidemiology, histopathology, prognosis, and treatment, EC can appear as type 1 (endometrioid), affecting approximately $80 \%$ of patients, and type 2 (nonendometrioid), affecting approximately $20 \%$ of patients $[78,85,88]$. Type 1 tumors develop from atypical glandular hyperplasia. This type is related to long-lasting unopposed estrogen stimulation and often preceded by endometrial hyperplasia $[3,90]$. The molecular basis of this process is not clear yet [3].

Carcinomas of type 1 are associated with significant incidences of CTNNB1, KRAS, and POLE oncogene mutations; phosphatase and tensin homolog (PTEN) tumor suppressor gene; defects in deoxyribonucleic acid (DNA) mismatch repair; and near-diploid karyotype (Table 2) $[3,88,104]$. From a molecular point of view, ECs resemble proliferative rather than secretory endometrium $[3,78]$. Specific tumor suppressor gene, PTEN that is expressed most highly in an estrogen-rich environment, could be responsible for the disease development. Progestogens affect PTEN expression and promote involution of PTEN-mutated endometrial cells in various histopathological settings $[3,78]$. This hypothesis can explain therapeutic effect of progestogens in EC cases.

Table 2. Molecular mechanisms of endometrial cancer development.

\begin{tabular}{|c|c|c|}
\hline Endometrial Cancer Type & Molecular Factors/Genes & $\begin{array}{c}\text { Changes in Function Leading to } \\
\text { Endometrial Cancer }\end{array}$ \\
\hline \multicolumn{3}{|c|}{ Type 1} \\
\hline & CTNNB1 & Mutation \\
\hline & POLE & Mutation \\
\hline & $K R A S$ & Mutation \\
\hline & PTEN & Loss \\
\hline & $A K T$ & Up-regulation \\
\hline & PI3KSA & Up-regulation \\
\hline & $\mathrm{G}_{1} / \mathrm{S}$ cell cycle phase & Progression \\
\hline & Bcl-2 & Loss of down-regulation \\
\hline & MLH1/MSH6 & Instability \\
\hline & DNA & Mismatch \\
\hline \multicolumn{3}{|c|}{ Type 2} \\
\hline & TP53 & Mutation \\
\hline & ERBB-2 (HER2/neu) & Overexpression \\
\hline & $p-16$ & Inactivation \\
\hline & E-cadherin & Reduction \\
\hline
\end{tabular}


Type 2 tumors include predominantly unspecified EC, clear-cell, carcinosarcoma and high-grade EC, and mixed (typically endometrioid and a high-grade non-endometrioid pattern) variants [103]. Type 2 tumors are associated with mutations in TP53 and ERBB-2 (HER2/neu) overexpression (Table 2) [3]. The features of endometrial serous carcinomas are the following: presence of TP53 mutations, an overall low mutation rate, and frequent copy-number alterations [88].

For the majority of EC cases, sporadic mutations are responsible; however, approximately $5 \%$ of EC cases are caused by inherited genetic mutations. EC caused by genetic predispositions typically occur 10 to 20 years before sporadic EC [90]. The following syndromes are known to predispose to EC:

1. Lynch syndrome (LS), an autosomal dominant syndrome, results from a germline mutation in one of four DNA mismatch repair genes-MLH1, MSH2, MSH6, or PMS2 [90]. It is associated with significantly increased lifetime risk of colorectal, ECs and some other cancers $[90,105]$.

2. Cowden syndrome: Cowden syndrome is an autosomal dominant syndrome characterized by PTEN mutations. It is associated with a $19 \%$ to $28 \%$ risk of EC by age 70 [90].

Currently, there is no approved effective screening program for EC. However, for patients with genetic syndromes, because of the significantly increased risk of the disease onset in reproductive age, the ACS recommends annual EC screening with endometrial biopsies starting at age $35[85,90,105]$.

\subsection{Clinical Presentation and Diagnostic Tools}

Nowadays, for the general population there are no approved screening programs for the early detection of EC [90].

Patients' evaluation should include thorough history taking, especially focusing on family history and possible risk factors [90]. Symptoms of EC are non-specific; thus, diagnosis of the condition is challenging in some cases. Abnormal uterine bleeding (AUB) is the most common symptom of endometrial cancer and is present in $90 \%$ of affected patients $[3,84,85,90,106,107]$. However, this symptom appears to be present in many other female genital disorders. Furthermore, as AUB can also be a sign of EC in premenopausal women, who comprise $20 \%$ of cases of EC, the approach to a patient with abnormal uterine bleeding will depend on the age group this patient belongs to (reproductive or postmenopausal) $[79,84,85]$. All postmenopausal women with AUB, especially if any of the risk factors discussed above are present $[108,109]$, should undergo endometrial biopsy $[3,79,84]$. The risk of EC in postmenopausal women with uterine bleeding is up to $10 \%[3,84,90]$.

Women may also present with vague complaints of increased vaginal discharge or an incidental finding of a thickened endometrium on imaging [90]. Patients with advanced stages of the disease may complain of pelvic pain, abdominal distension, early satiety, changes in bowel or bladder function, pain during intercourse, and dyspnea because of pleural effusion [90]. However, it is important to keep in mind that up to $5 \%$ of patients with EC are asymptomatic [3,90].

Transvaginal ultrasound (TVUS) is a widely used approach for further investigations in patients suffering from AUB $[3,85]$. After the thorough investigation via sonography, the vast majority will undergo endometrial sampling $[110,111]$. The most useful approach to diagnose and confirm EC is endometrial sampling with histological examination $[3,84,106,107]$.

The strategy with TVUS, followed by endometrial biopsy if an abnormality is detected, is the most cost-effective; therefore, TVUS is considered as the first step in any woman presenting with AUB $[3,85,112,113]$.

Endometrial biopsy could be performed using different devices [84]. However, the most popular are the following methods: dilation and curettage (D\&C), Pipelle sampling (Pipelle de Cornier prototype), and hysteroscopy with targeted biopsy. Histological ex- 
amination reports may include presence of endometrial cells, atypical glandular cell of uncertain significance, or adenocarcinoma in situ $[3,85,90]$.

\section{Molecular Basis of Endometriosis and Endometrial Pathology}

\subsection{Genetic and Epigenetic Changes in Endometriosis}

\subsubsection{Genetic Association and Meta-Analyses Studies}

Endometriosis is a complex disease with multiple genetic and environmental factors contributing to disease pathology $[114,115]$. First evidence for the presence of a heritable component contributing to endometriosis came from studies published as early as the 1950s [116] that demonstrated familial clustering of endometriosis [117-119]. These studies showed that first-degree relatives of affected women have a five to seven times higher risk of being diagnosed with endometriosis $[117,118]$. Familial endometriosis was further shown to be associated with earlier age of symptom onset and a more severe disease course [120]. The genetic predisposition to endometriosis was corroborated by twin studies that showed an increased disease risk in monozygotic versus dizygotic twins, and the estimated contribution of genetic factors to endometriosis was up to $51 \%$ [121].

Large-scale genetic linkage and meta-analyses represented an important means to identify endometriosis susceptibility loci [122]. Most notable, family-based linkage studies of endometriosis conducted by the International Endogene Consortium in two combined cohorts of Australian and UK families identified two linkage regions that likely harbor rare causal variants, one on chromosome 10q26 [123] and one on chromosome 7p13-15 [124]. A third region of suggestive linkage identified by Treloar et al. is located on chromosome 20 p13 [123]. Chromosome 10q26 contains two genes that were previously implicated in candidate gene mapping studies as potential endometriosis risk loci, EMX2 [125], which encodes a transcription factor required for reproductive-tract development [126], and the tumor suppressor gene PTEN, which encodes a phosphatidylinositol-3,4,5-triphosphate 3-phosphatase [88].

Both EMX2 and PTEN were previously reported to be aberrantly expressed in endometrial lesions [125,127-130]. However, systematic resequencing of the region could not confirm either gene as an endometriosis risk locus [131]. Instead, CYP2C19 (Cytochrome P450 Family 2 Subfamily C Member 19), a nearby gene, was found to be weakly associated with endometriosis $[132,133]$. CYP2C19 is a member of the cytochrome p450 family and encodes an aromatase associated with the metabolism of drugs and estrogen $[134,135]$. The linkage peak on chromosome 7p13-15 may represent a susceptibility allele with high penetrance for more severe forms of endometriosis [123], but the involved allele remains elusive.

Other genome-wide association studies conducted in women of European ancestry led to the identification of two new genomic regions associated with a significant risk of endometriosis. The first locus with significant disease association was located to chromosome 7 p15.2 [135]; this region may regulate expression levels of nearby gene(s) involved in the development of the uterus and endometrium [136]. A second genetic variant was mapped to chromosome 1p36.12 near the WNT4 gene [136], which is implicated in the development and function of the female reproductive tract and sex hormone metabolism. Both risk loci were independently confirmed in Japanese and European cohorts [137,138].

Genome-wide studies identified additional susceptibility loci for endometriosis [139-142]. Several candidate genes were mapped that exhibit varying degrees of disease association including genes involved in hormone signaling (GREB1), cell proliferation and differentiation (ID4, CDKN2PAS), as well as cell migration and invasion (FN1, VEZT) $[137,138,143]$. However, most polymorphisms identified by genome-wide association studies to date are located in non-coding regions, suggesting they affect the expression of nearby genes $[137,138]$.

In conclusion, genome-wide association studies, with few exceptions, failed to confirm a clear association between endometriosis and specific risk loci. This may indicate that there are many genetic variants, each of which has a weak impact on endometriosis development, yet in combination they can significantly increase the likelihood of endometriosis and, thus, represent true endometriosis risk loci [144-146]. Detection of weak effects of gene 
variants influencing a complex trait such as endometriosis, therefore, requires datasets of significant size.

\subsubsection{Genome Mapping Studies and Targeted Gene Sequencing}

In addition to genome-wide association studies, candidate gene approaches were used to test the association of specific genes with endometriosis. These studies focused on systematic sequencing of identified risk loci or used genetic mapping where variants of a gene of interest with an inferred pathophysiological relevance are tested for association with the disease in samples of endometriosis cases and controls. These approaches identified genes involved in sex hormone metabolism and signaling, growth factor signaling, cell adhesion, apoptosis, cell-cycle regulation, detoxification, and inflammation [138]. Several studies also reported genetic aberrations in tumor suppression genes, such as TP53 and PTEN, in endometriotic tissues [88]. However, most associations identified by targeted gene mapping approaches suffered from low statistical power and lack of replication $[145,146]$.

\subsubsection{Genome-Wide Sequencing Studies}

Endometriosis is characterized by the growth of ectopic endometrial-like epithelium and stroma $[40,41]$ with neoplastic characteristics that shares striking similarities with malignancy [147]. Indeed, endometriosis shares many of the key hallmarks of cancer including resistance to apoptosis, stimulation of angiogenesis, invasion, and inflammation [148]. Moreover, endometriosis is well-established as the precursor of clear cell and endometrioid ovarian carcinomas [149]. A plausible link between benign endometriosis and endometriosis associated cancer was provided by several recent next-generation sequencing approaches [121-124]. These studies also offered important insight into the molecular basis of cancer development.

Anglesio et al. were the first to report on the genome-wide identification of somatic cancer driver mutations in deep infiltrating endometriosis [150]. Deep endometriosis represents a subtype of endometriosis that occurs under the peritoneum [40] and rarely undergoes a malignant transformation. The cited authors identified somatic mutations in PIK3CA, KRAS, and PPP2R1A, which encodes a regulatory subunit of protein phosphatase 2 . In addition, frequent loss of function mutations in AT-rich interactive domain 1A (ARID1A) were detected, altogether affecting approximately one-quarter of patients subjected to comprehensive genomic analysis [150]. Targeted sequencing of a subpopulation of patients further identified KRAS activating mutations in one-quarter of deep endometriosis patient samples [150]. Overall, of the 24 women taking part in the study, 19 had one or more driver mutations in their endometriosis tissue that were not present in their normal tissue [151,152]. Notably, cancer-associated mutations were found only in laser microdissected epithelial cells of ovarian and extraovarian pelvic endometriotic tissues, but not in stromal cells of the same tissue. These findings suggest that the occurrence of driver mutations in the epithelium is clonal and contributes to endometriosis development independently of stroma [152].

Besides ARID1A, PIK3CA, KRAS, and PPP2R1A, several other cancer-associated genes, such as PTEN, PIK3R1, TP53, FBXW7, and CTNNB1, were recurrently mutated in both endometriotic and uterine endometrial epithelium samples. In particular, KRAS and ARID1 are frequently mutated in the endometriotic epithelium, although these epithelia were histologically benign and normal [153,154]. All of these mutations are well characterized cancer driver mutations that are known for controlling cell proliferation and survival, angiogenesis, invasion, and DNA damage repair. Importantly, besides deep endometriosis [150], other types of endometriosis also contained somatic cancer driver mutations, including endometriotic cysts, iatrogenic endometriosis as a rare complication associated with laparoscopic supracervical hysterectomy (LASH), and eutopic normal endometrial epithelium [151,155].

How precisely cancer driver mutations affect endometriosis in histologically normal tissue is still an outstanding question. The presence of these mutations in benign endometri- 
otic lesions is clearly non-random. However, affected epithelial cells only carried one to two somatic mutations, which is not sufficient for malignant transformation [156]. Given the known roles of driver mutations in cancer progression, one can speculate that these mutations are necessary for driving the growth of endometriotic tissue in other regions of the body. Only accumulation of additional driver mutations in combination with microenvironmental factors, such as chronic estrogen exposure and/or inflammation, may then lead to cancer development.

\subsection{Endometrial Stem Cells in Pathogenesis of Endometrial Pathology}

There are several theories to account for the origin of endometriosis and to explain how tissue can be scattered throughout the abdominal cavity. However, there is no single theory that can explain all clinical presentations and pathological features observed in endometriosis, and several mechanisms may in fact contribute.

The stem cell origin theory of endometriosis has gained considerable attention in recent years following the advances in molecular and genetic findings. There are two main models that are differentiated based on the tissue origin of the stem cells: stem cells arising from the regenerating uterine endometrium or stem cells originating from the bone marrow. The uterus in women is the only organ that undergoes repeated cycles of physiological damage, repair, and regeneration following menstrual shedding [114-116]. Menstrual shedding, and the subsequent repair of the endometrial functionalis, is a process unique to humans and higher-order primates [117-119]. These approximately 400 cycles of shedding and regeneration occur over a woman's lifetime. This significant regenerative capacity is thought to be driven by stem cells that reside in the terminal ends of the basalis glands at the endometrial/myometrial interface, also termed endometrial functionalis layer, which persists after menstruation and regenerates the epithelium during the proliferative phase in response to estrogen [9]. The first model proposes that circulating epithelial progenitor or stem cells intended to regenerate the uterine endometrium are shed with menstruation and may become aberrantly activated and trapped outside the uterus, thus giving rise to ectopic lesions after retrograde menstruation and trans-tubal migration in to the pelvic cavity [157].

Irrespective of the site of stem cell origin, the growth of the ectopic tissue, which retains hormone responsiveness, is further influenced by sex hormones and other factors present in the microenvironment. These factors collectively control the adhesion, proliferation, angiogenesis, and invasion of the trapped progenitor cells. The ectopic tissue, in turn, induces the recruitment of immune cells leading to local inflammation and the formation of a dysregulated inflammation-hormonal autoregulatory loop. The trapped progenitor cells thereby may form nascent glands in the epithelium through clonal expansion leading to the establishment of deep infiltrating endometriosis.

However, more studies for a better understanding of endometrial epithelial stem cell function and regulation are required to understand the eventual changes behind the endometrial pathologies.

\subsection{Endometriosis as a Risk Factor for Endometrial Cancer}

With respect to endometriosis itself as a risk factor for other conditions, women with endometriosis have a higher risk of infection, allergy, autoimmune disease, psychiatric conditions, preterm birth, metabolic syndrome, coronary heart disease, and cancer, especially ovarian [158] and breast cancers, and melanoma [159].

A history of endometriosis has been recognized as a precursor lesion of several types of malignancies and endometriosis-associated carcinoma [160,161].

Some investigations suggested no association between endometriosis and EC [28,149, 160,162-164]. One of the recent systematic reviews performed to search for evidence on the association of endometriosis with gynecological cancers also reported no clear association between endometriosis and EC [165]. On the other hand, some studies have reported an association between endometriosis and $\mathrm{EC}$ reflecting overlapping risk factors between the 
two conditions, including endogenous or exogenous hyperestrogenism and ovulatory dysfunction $[160,166]$. Another recent epidemiologic study on the association of endometriosis with malignancy reported that patients with endometriosis were significantly more likely to be diagnosed with EC at a younger age than those without endometriosis (mean age at EC diagnosis 57 years vs. 62 years; $p=5.0 \times 10^{-11}$ ) [167]. Moreover, two population-based studies have shown associations between endometriosis and EC [52,168,169].

If we analyze the role of risk factors in the development of endometriosis and EC, some overlapping genetic factors (Figure 1) are worth highlighting. Genetic correlation analyses by Painter et al. (2018) revealed the presence of "weak to moderate, but significant" genetic overlap between endometriosis and EC [52,144]. Namely, in the cross-disease metaanalysis the authors found $13 \mathrm{SNPs}$ that appeared to be involved in replication. These SNPs are the following: rs2475335, rs9865110, rs2278868, rs12303900, rs9349553, rs10008492, rs9530566, rs10459129, rs2198894, rs7042500, rs17693745, rs7515106, and rs1755833 [52,144]. SNP rs2475335, which is located on chromosome 9p23, was most significantly associated with both diseases $\left(p=4.9 \times 10^{-8}\right)$ [52].

To conclude about the link between endometriosis and EC, epidemiological studies have reported conflicting data for an association between the diagnosis of endometriosis and risk of EC [52]. More large-scale investigations are required in order to confirm or refute the link between endometriosis and risk of EC development.

\section{Clinical Applications of Current Knowledge and Directions for Future Research}

\subsection{Molecular Basis for a Specific Therapeutic Approach}

Collectively, studies performed over the last decade shed new light on the pathophysiology of endometriosis. Linkage and sequencing studies have identified genes and pathways important for endometriosis development and have highlighted potential causal links between endometriosis and endometriosis-associated cancer. The identification of women with endometriosis who are at risk of cancer development provides a basis for improved diagnosis and prognosis and is likely to aid in improved cancer surveillance of patients at risk.

As treatment of endometrial cancer was based on histological characteristics and staging [170,171], prognosis was not promising, especially if the stage is advanced [172-174]. Therefore, in the last couple of years, efforts have been directed to molecular aberrations within the specific tumor, as a novel biological targeted therapy with promising outcomes in clinical trials [175].

Various biomarkers [176], such as mTOR pathway disruptions, loss of estrogen and progesterone nuclear expression, TP53 mutation, changes in Wnt-signaling, or L1CAM expression, were identified as a link to endometrial cancer development [177]. All these mutations were associated with poor prognosis, but their clinical utilization is still questionable.

Preclinical investigations related to molecular-targeted therapies in ECs enabled deeper understanding of underlying mechanisms and highlighted different approaches to EC patients.

According to genomic characteristics of 373 endometrial carcinomas, The Cancer Genome Atlas (TCGA) classified EC into four molecular subtypes [178,179], which differ a lot from the molecular point, underlying risk factors, clinical and pathological features, treatment modalities, and prognosis [180-182]. These four distinct prognostic groups are POLE ultramutated, microsatellite instability/hypermutated, copy number-low microsatellite stable, and copy number-high/serous like.

Compared with other subtypes of tumors, prognosis for the copy number-high/serouslike group of patients is poor [183]. Poor prognosis is related to the loss of tumor suppressor TP53 resulting in a high degree of genomic instability and rapid tumor progression and invasion [184,185]. As one-quarter of serous-like tumors have ERBB2 overexpression, there is a need to investigate the role of human epidermal growth factor receptor 2 (HER2)targeted inhibitors [186-188]. Considering molecular similarities between high-grade endometrioid and serous carcinomas, patients of this subtype may benefit from treatment 
as if their tumor was serous. Moreover, specific mutations and overexpression of molecular targets in these tumors could tailor treatment in both the primary and recurrent setting.

From the clinical point of view, there is a need to create an integrated molecular risk profile for endometrial cancer. For that purpose, these four molecular subgroups were combined with additional molecular markers. Integrated molecular and clinico-pathologic risk assessment was based on a multivariate analysis of four molecular subgroups, clinical and histopathological characteristics of tumors, and various molecular classifiers. Molecular markers involved were TP53 expression, MSI, POLE mutation, protein expression of L1CAM, ARID1a, PTEN, ER/PR, as well as analysis of 13 genes found to have variable expression in the TCGA classification groups (BRAF, CDKNA2, CTNNB1, FBXW7, FGFR2, FGFR3, FOXL2, HRAS, KRAS, NRAS, PIK3CA, PPP2R1A, and PTEN). This integrated model for prediction of endometrial cancer recurrence was confirmed to be more reliable than the traditional one relying on clinical and pathologic factors [189]. Moreover, this classification system enhances risk stratification of endometrial cancers. Importance for molecular subtyping was confirmed in clinical practice, as sorting of patients into molecular subgroups was confirmed to predict response rates to conventional, targeted systemic and radiotherapy $[190,191]$. For clinicians, molecular subtype stratification could be used in both preoperative evaluation (whether to prepare the whole set up for lymph node dissection or not) and postoperative treatment (the need for eventual adjuvant therapy). Moreover, molecular subtyping was confirmed to be very important for targeted therapy in patients with recurrent and metastatic diseases [175,177,192-194]. Thus, once the diagnosis of endometrial cancer has been established, there is a need to perform molecular subtyping, which will enable proper therapeutic approach.

\subsection{Prognostic Biomarkers for Endometrial Cancer}

There is no screening method for EC for the general population. Women with LS and their first-degree relatives are offered annual screening with TVUS and endometrial biopsy from the age of 35 years $[90,105]$.

There are several types of biomarkers: gene-based biomarkers, proteins biomarkers, and hormonal biomarkers [105]. Gene-based biomarkers include the following: PTEN, TP53, microribonucleic acids (microRNAs), circulating tumor DNA, and DNA methylation. Protein biomarkers include $p R b 2 / p 130, K i$ 67, ARID1A, cell adhesion molecules (CAMs), phosphohistone-H3 ( $p H H 3)$, angiotensin factors, etc. The most commonly mutated genes detected in EC patients using Tao brush samples were PTEN and TP53 [83].

One of the gene-based biomarkers, PTEN tumor suppressor, antagonizes the phosphoinositol-3-kinase/ AKT signaling pathway, suppressing cell survival as well as cell proliferation [105]. A recent study suggests that PTEN expression in endometrial hyperplasia can be used as an early warning of heightened cancer risk [105,195]. Complete loss of $P T E N$ protein expression is most commonly found in EC and endometrial hyperplasia with cytological atypia.

Another potentially useful molecular biomarker is TP53, which belongs to cell cycle proteins [105], and triggers cellular responses that can lead to cell-cycle arrest, senescence, differentiation, DNA repair, apoptosis, and inhibition of angiogenesis [196]. The role of TP53 in EC and hyperplasia has been studied, showing that TP53 gene mutation is present in EC, but it is absent in endometrial hyperplasia $[105,197]$.

The expression of the cell cycle regulator $p R b 2 / p 130$ was evaluated in EC and endometrial hyperplasia and was found to be highly expressed in the proliferative endometrium and in hyperplasia without atypia, but it was downregulated in secretory endometrium, atypical hyperplasia, and EC [105,197].

The most promising serum biomarker for EC is human epididymis protein 4 (HE4) [105]. A number of studies have looked at HE4 as a prognostic marker for EC [86,105,198,199]. Diagnostic levels range between 50 and $70 \mathrm{pmol} / \mathrm{L}$, with a minimum $78 \%$ sensitivity and $100 \%$ specificity, even in early-stage disease $[105,198]$. Serum HE4 levels are found to 
be significantly higher in advanced stages of EC $[105,199]$ and are predictive for disease recurrence [105].

There are many novel biomarkers under investigation. Introduction of them into clinical practice could improve timely EC diagnosis, treatment outcomes, and surveillance of EC patients.

\section{Conclusions}

Although diagnostic methods of endometriosis are well-developed in modern gynecology, the etiopathogenesis of the disease remains largely unknown. Lack of clear understanding of the pathologic process leads to inferable outcomes in patients suffering from endometriosis and may be linked to development of related female genital malignancy. Existing studies have reported inconclusive data for an association between endometriosis and risk of EC. Further large-scale investigations could help to answer this query. Molecular studies of endometrial tissue function and endometriosis might shed light on the real cause of the condition and the factors leading to EC development. As a result of a better understanding of the molecular basis of endometriosis and $\mathrm{EC}$, patient management and outcomes could be improved.

Author Contributions: Conceptualization, M.T. and A.S.L.; methodology, M.T., A.S.L.; resources, M.T.; data curation, G.A., G.B., S.T.; writing—original draft preparation, G.A., J.K., B.A.; writingreview and editing, M.T., A.S.L.; supervision, G.B.; project administration, M.T.; funding acquisition, M.T. All authors have read and agreed to the published version of the manuscript.

Funding: This study was supported by the Nazarbayev University Grant Number 110119FD4540, 2019-2021.

Institutional Review Board Statement: Not applicable.

Informed Consent Statement: Not applicable.

Data Availability Statement: No raw data to share.

Conflicts of Interest: The authors declare no conflict of interest.

\section{References}

1. Garry, R.; Hart, R.; Karthigasu, K.A.; Burke, C. A re-appraisal of the morphological changes within the endometrium during menstruation: A hysteroscopic, histological and scanning electron microscopic study. Hum. Reprod. 2009, 24, 1393-1401. [CrossRef]

2. Emera, D.; Wagner, G. Transposable element recruitments in the mammalian placenta: Impacts and mechanisms. Brief. Funct. Genom. 2012, 11, 267-276. [CrossRef]

3. Amant, F.; Moerman, P.; Neven, P.; Timmerman, D.; Van Limbergen, E.; Vergote, I. Endometrial cancer. Lancet 2005, 366, 491-505. [CrossRef]

4. Yamaguchi, M.; Yoshihara, K.; Suda, K.; Nakaoka, H.; Yachida, N.; Ueda, H.; Sugino, K.; Mori, Y.; Yamawaki, K.; Tamura, R.; et al. Three-dimensional understanding of the morphological complexity of the human uterine endometrium. iScience 2021, 24, 102258. [CrossRef]

5. Cooke, P.S.; Spencer, T.; Bartol, F.F.; Hayashi, K. Uterine glands: Development, function and experimental model systems. Mol. Hum. Reprod. 2013, 19, 547-558. [CrossRef]

6. Gray, C.A.; Bartol, F.F.; Tarleton, B.J; Wiley, A.A.; Johnson, G.A.; Bazer, F.W.; Spencer, T.E. Developmental Biology of Uterine Glands1. Biol. Reprod. 2001, 65, 1311-1323. [CrossRef] [PubMed]

7. Kyo, S.; Maida, Y.; Inoue, M. Stem cells in endometrium and endometrial cancer: Accumulating evidence and unresolved questions. Cancer Lett. 2011, 308, 123-133. [CrossRef]

8. Miyazaki, K.; Maruyama, T.; Masuda, H.; Yamasaki, A.; Uchida, S.; Oda, H.; Uchida, H.; Yoshimura, Y. Stem Cell-Like Differentiation Potentials of Endometrial Side Population Cells as Revealed by a Newly Developed In Vivo Endometrial Stem Cell Assay. PLoS ONE 2012, 7, e50749. [CrossRef]

9. Prianishnikov, V.A. A functional model of the structure of the epithelium of normal, hyperplastic, and malignant human endometrium: A review. Gynecol. Oncol. 1978, 6, 420-428. [CrossRef]

10. Garry, R.; Hart, R.; Karthigasu, K.; Burke, C. Structural changes in endometrial basal glands during menstruation. BJOG Int. J. Obstet. Gynaecol. 2010, 117, 1175-1185. [CrossRef]

11. Gellersen, B.; Brosens, J. Cyclic Decidualization of the Human Endometrium in Reproductive Health and Failure. Endocr. Rev. 2014, 35, 851-905. [CrossRef] 
12. Santamaria, X.; Mas, A.; Cervelló, I.; Taylor, H.; Simón, C. Uterine stem cells: From basic research to advanced cell therapies. Hum. Reprod. Updat. 2018, 24, 673-693. [CrossRef]

13. E McLennan, C.; Rydell, A.H. Extent of endometrial shedding during normal menstruation. Obstet. Gynecol. 1965, $26,605-621$.

14. Filho, J.H.; Cedenho, A.P.; De Freitas, V. Correlation between endometrial dating of luteal phase days 6 and 10 of the same menstrual cycle. Sao Paulo Med. J. 1998, 116, 1734-1737. [CrossRef]

15. Johannisson, E.; Parker, R.A.; Landgren, B.-M.; Diczfalusy, E. Morphometric analysis of the human endometrium in relation to peripheral hormone levels. Fertil. Steril. 1982, 38, 564-571. [CrossRef]

16. García-Solares, J.; Donnez, J.; Donnez, O.; Dolmans, M.-M. Pathogenesis of uterine adenomyosis: Invagination or metaplasia? Fertil. Steril. 2018, 109, 371-379. [CrossRef] [PubMed]

17. Koninckx, P.R.; Ussia, A.; Adamyan, L.; Wattiez, A.; Gomel, V.; Martin, D.C. Pathogenesis of endometriosis: The genetic/epigenetic theory. Fertil. Steril. 2019, 111, 327-340. [CrossRef] [PubMed]

18. Morice, P.; Leary, A.; Creutzberg, C.; Abu-Rustum, N.; Darai, E. Endometrial cancer. Lancet 2016, 387, 1094-1108. [CrossRef]

19. Matalliotaki, C.; Matalliotakis, M.; Zervou, M.I.; Patelarou, A.; Koliarakis, I.; Spandidos, D.A.; Arici, A.; Matalliotakis, I.; Goulielmos, G.N. Epidemiological aspects of the outcomes from the treatment of endometriosis: Experience from two different geographical areas. Exp. Ther. Med. 2019, 19, 1079-1083. [CrossRef]

20. Johnatty, S.E.; Tan, Y.; Buchanan, D.D.; Bowman, M.; Walters, R.J.; Obermair, A.; Quinn, M.A.; Blomfield, P.B.; Brand, A.; Leung, Y.; et al. Family history of cancer predicts endometrial cancer risk independently of Lynch Syndrome: Implications for genetic counselling. Gynecol. Oncol. 2017, 147, 381-387. [CrossRef]

21. Laganà, A.S.; Vitale, S.G.; Salmeri, F.M.; Triolo, O.; Frangež, H.B.; Vrtačnik-Bokal, E.; Stojanovska, L.; Apostolopoulos, V.; Granese, R.; Sofo, V. Unus pro omnibus, omnes pro uno: A novel, evidence-based, unifying theory for the pathogenesis of endometriosis. Med. Hypotheses 2017, 103, 10-20. [CrossRef] [PubMed]

22. Raffaelli, R.; Garzon, S.; Baggio, S.; Genna, M.; Pomini, P.; Laganà, A.S.; Ghezzi, F.; Franchi, M. Mesenteric vascular and nerve sparing surgery in laparoscopic segmental intestinal resection for deep infiltrating endometriosis. Eur. J. Obstet. Gynecol. Reprod. Biol. 2018, 231, 214-219. [CrossRef]

23. Bulun, S.E. Endometriosis. N. Engl. J. Med. 2009, 360, 268-279. [CrossRef]

24. E Bulun, S.; Yilmaz, B.D.; Sison, C.; Miyazaki, K.; Bernardi, L.; Liu, S.; Kohlmeier, A.; Yin, P.; Milad, M.; Wei, J. Endometriosis. Endocr. Rev. 2019, 40, 1048-1079. [CrossRef] [PubMed]

25. Falcone, T.; Flyckt, R. Clinical Management of Endometriosis. Obstet. Gynecol. 2018, 131, 557-571. [CrossRef] [PubMed]

26. Terzic, M.; Aimagambetova, G.; Garzon, S.; Bapayeva, G.; Ukybassova, T.; Terzic, S.; Norton, M.; Laganà, A.S. Ovulation induction in infertile women with endometriotic ovarian cysts: Current evidence and potential pitfalls. Minerva Med. 2020, 111 , 50-61. [CrossRef]

27. Hemmert, R.; Schliep, K.C.; Willis, S.; Peterson, C.M.; Louis, G.B.; Allen-Brady, K.; Simonsen, S.E.; Stanford, J.B.; Byun, J.; Smith, K.R. Modifiable life style factors and risk for incident endometriosis. Paediatr. Périnat. Epidemiol. 2019, 33, 19-25. [CrossRef] [PubMed]

28. Shafrir, A.; Farland, L.; Shah, D.; Harris, H.; Kvaskoff, M.; Zondervan, K.; Missmer, S. Risk for and consequences of endometriosis: A critical epidemiologic review. Best Pr. Res. Clin. Obstet. Gynaecol. 2018, 51, 1-15. [CrossRef] [PubMed]

29. Adam, A.M.; Altalhi, T.A.; El-Megharbel, S.M.; Saad, H.A.; Refat, M.S. Using a Modified Polyamidoamine Fluorescent Dendrimer for Capturing Environment Polluting Metal Ions Zn2+, Cd2+, and Hg2+: Synthesis and Characterizations. Crystals 2021, 11, 92. [CrossRef]

30. Capezzuoli, T.; Clemenza, S.; Sorbi, F.; Campana, D.; Vannuccini, S.; Chapron, C.; Petraglia, F. Classification/staging systems for endometriosis: The state of the art. Gynecol. Reprod. Endocrinol. Metab. 2020, 1, 14-22.

31. Canis, M.; Donnez, J.G.; Guzick, D.S.; Halme, J.K.; Rock, J.A.; Schenken, R.S.; Vernon, M.W. Revised American Society for Reproductive Medicine classification of endometriosis: 1996. Fertil. Steril. 1997, 67, 817-821. [CrossRef]

32. Vercellini, P.; Viganò, P.; Somigliana, E.; Fedele, L. Endometriosis: Pathogenesis and treatment. Nat. Rev. Endocrinol. 2014, 10, 261-275. [CrossRef] [PubMed]

33. Laganà, A.S.; Vitale, S.G.; Trovato, M.A.; Palmara, V.I.; Rapisarda, A.M.C.; Granese, R.; Sturlese, E.; De Dominici, R.; Alecci, S.; Padula, F.; et al. Full-Thickness Excision versus Shaving by Laparoscopy for Intestinal Deep Infiltrating Endometriosis: Rationale and Potential Treatment Options. BioMed Res. Int. 2016, 2016, 3617179. [CrossRef] [PubMed]

34. Mehedintu, C.; Plotogea, M.N.; Ionescu, S.; Antonovici, M. Endometriosis still a challenge. J. Med. Life 2014, 7, 349-357. [PubMed]

35. Maruyama, S.; Imanaka, S.; Nagayasu, M.; Kimura, M.; Kobayashi, H. Relationship between adenomyosis and endometriosis; Different phenotypes of a single disease? Eur. J. Obstet. Gynecol. Reprod. Biol. 2020, 253, 191-197. [CrossRef]

36. Tosti, C.; Pinzauti, S.; Santulli, P.; Chapron, C.; Petraglia, F. Pathogenetic Mechanisms of Deep Infiltrating Endometriosis. Reprod. Sci. 2015, 22, 1053-1059. [CrossRef] [PubMed]

37. Guo, S.-W. The Pathogenesis of Adenomyosis vis-à-vis Endometriosis. J. Clin. Med. 2020, 9, 485. [CrossRef]

38. Chapron, C.; Tosti, C.; Marcellin, L.; Bourdon, M.; Lafay-Pillet, M.-C.; Millischer, A.-E.; Streuli, I.; Borghese, B.; Petraglia, F.; Santulli, P. Relationship between the magnetic resonance imaging appearance of adenomyosis and endometriosis phenotypes. Hum. Reprod. 2017, 32, 1393-1401. [CrossRef]

39. Rolla, E. Endometriosis: Advances and controversies in classification, pathogenesis, diagnosis, and treatment. F1000Research 2019, 8, 529. [CrossRef] 
40. Vitale, S.G.; La Rosa, V.L.; Rapisarda, A.M.C.; Laganà, A.S. Impact of endometriosis on quality of life and psychological well-being. J. Psychosom. Obstet. Gynecol. 2016, 38, 317-319. [CrossRef]

41. Brasil, D.L.; Montagna, E.; Trevisan, C.M.; La Rosa, V.L.; Laganà, A.S.; Barbosa, C.P.; Bianco, B.; Zaia, V. Psychological stress levels in women with endometriosis: Systematic review and meta-analysis of observational studies. Minerva Med. 2020, 111, 90-102. [CrossRef]

42. Abrao, M.S.; Miller, C.E. An endometriosis classification, designed to be validated. NewsScope 2012, 25, 6 .

43. Dai, Y.; Li, X.; Shi, J.; Leng, J. A review of the risk factors, genetics and treatment of endometriosis in Chinese women: A comparative update. Reprod. Health 2018, 15, 82. [CrossRef] [PubMed]

44. Baranov, V.S.; Ivaschenko, T.E.; Liehr, T.; Yarmolinskaya, M.I. Systems genetics view of endometriosis: A common complex disorder. Eur. J. Obstet. Gynecol. Reprod. Biol. 2015, 185, 59-65. [CrossRef] [PubMed]

45. Laganà, A.S.; Garzon, S.; Götte, M.; Viganò, P.; Franchi, M.; Ghezzi, F.; Martin, D.C. The Pathogenesis of Endometriosis: Molecular and Cell Biology Insights. Int. J. Mol. Sci. 2019, 20, 5615. [CrossRef]

46. Williams, C.; Long, A.J.; Noga, H.; Allaire, C.; Bedaiwy, M.A.; Lisonkova, S.; Yong, P.J. East and South East Asian Ethnicity and Moderate-to-Severe Endometriosis. J. Minim. Invasive Gynecol. 2018, 26, 507-515. [CrossRef] [PubMed]

47. Missmer, S.A.; Hankinson, S.E.; Spiegelman, D.; Barbieri, R.L.; Marshall, L.M.; Hunter, D.J. Incidence of Laparoscopically Confirmed Endometriosis by Demographic, Anthropometric, and Lifestyle Factors. Am. J. Epidemiol. 2004, 160, 784-796. [CrossRef] [PubMed]

48. McLeod, B.S.; Retzloff, M.G. Epidemiology of endometriosis: An assessment of risk factors. Clin. Obstet. Gynecol. 2010, 53, 389-396. [CrossRef] [PubMed]

49. Schliep, K.C.; Schisterman, E.; Mumford, S.; Pollack, A.; Zhang, C.; Ye, A.; Stanford, J.B.; O Hammoud, A.; Porucznik, C.; Wactawski-Wende, J. Caffeinated beverage intake and reproductive hormones among premenopausal women in the BioCycle Study. Am. J. Clin. Nutr. 2012, 95, 488-497. [CrossRef]

50. Fiuza-Luces, C.; Garatachea, N.; Berger, N.A.; Lucia, A. Exercise is the Real Polypill. Physiology 2013, 28, 330-358. [CrossRef]

51. Sofo, V.; Götte, M.; Laganà, A.S.; Salmeri, F.M.; Triolo, O.; Sturlese, E.; Retto, G.; Alfa, M.; Granese, R.; Abrão, M.S. Correlation between dioxin and endometriosis: An epigenetic route to unravel the pathogenesis of the disease. Arch. Gynecol. Obstet. 2015, 292, 973-986. [CrossRef] [PubMed]

52. Painter, J.N.; O’Mara, T.A.; Morris, A.P.; Cheng, T.H.T.; Gorman, M.; Martin, L.; Hodson, S.; Jones, A.; Martin, N.G.; Gordon, $\mathrm{S}$; ; et al. Genetic overlap between endometriosis and endometrial cancer: Evidence from cross-disease genetic correlation and GWAS meta-analyses. Cancer Med. 2018, 7, 1978-1987. [CrossRef] [PubMed]

53. Burney, R.O.; Giudice, L.C. Pathogenesis and pathophysiology of endometriosis. Fertil. Steril. 2012, 98, 511-519. [CrossRef]

54. Coxon, L.; Horne, A.W.; Vincent, K. Pathophysiology of endometriosis-associated pain: A review of pelvic and central nervous system mechanisms. Best Pr. Res. Clin. Obstet. Gynaecol. 2018, 51, 53-67. [CrossRef]

55. Sasson, I.E.; Taylor, H.S. Stem Cells and the Pathogenesis of Endometriosis. Ann. N. Y. Acad. Sci. 2008, 1127, 106-115. [CrossRef]

56. Poli-Neto, O.B.; Meola, J.; Rosa-E-Silva, J.C.; Tiezzi, D. Transcriptome meta-analysis reveals differences of immune profile between eutopic endometrium from stage I-II and III-IV endometriosis independently of hormonal milieu. Sci. Rep. 2020, 10, 313. [CrossRef] [PubMed]

57. Cousins, F.L.; Dorien, F.O.; Gargett, C.E. Endometrial stem/progenitor cells and their role in the pathogenesis of endometriosis. Best Pract. Res. Clin. Obstet. Gynaecol. 2018, 50, 27-38. [CrossRef] [PubMed]

58. Vetvicka, V.; Laganà, A.S.; Salmeri, F.M.; Triolo, O.; Palmara, V.I.; Vitale, S.G.; Sofo, V.; Kralickova, M. Regulation of apoptotic pathways during endometriosis: From the molecular basis to the future perspectives. Arch. Gynecol. Obstet. 2016, 294, 897-904. [CrossRef] [PubMed]

59. Salmeri, F.M.; Laganà, A.S.; Sofo, V.; Triolo, O.; Sturlese, E.; Retto, G.; Pizzo, A.; D’Ascola, A.; Campo, S. Behavior of Tumor Necrosis Factor- $\alpha$ and Tumor Necrosis Factor Receptor 1/Tumor Necrosis Factor Receptor 2 System in Mononuclear Cells Recovered From Peritoneal Fluid of Women With Endometriosis at Different Stages. Reprod. Sci. 2014, 22, 165-172. [CrossRef] [PubMed]

60. Sturlese, E.; Salmeri, F.M.; Retto, G.; Pizzo, A.; De Dominici, R.; Ardita, F.V.; Borrielli, I.; Licata, N.; Laganà, A.S.; Sofo, V. Dysregulation of the Fas/FasL system in mononuclear cells recovered from peritoneal fluid of women with endometriosis. $J$. Reprod. Immunol. 2011, 92, 74-81. [CrossRef]

61. Patel, B.G.; Lenk, E.E.; Lebovic, D.I.; Shu, Y.; Yu, J.; Taylor, R.N. Pathogenesis of endometriosis: Interaction between Endocrine and inflammatory pathways. Best Pract. Res. Clin. Obstet. Gynaecol. 2018, 50, 50-60. [CrossRef] [PubMed]

62. Chapron, C.; Marcellin, L.; Borghese, B.; Santulli, P. Rethinking mechanisms, diagnosis and management of endometriosis. Nat. Rev. Endocrinol. 2019, 15, 666-682. [CrossRef] [PubMed]

63. Terzic, M.; Aimagambetova, G.; Norton, M.; Della Corte, L.; Marín-Buck, A.; Lisón, J.F.; Amer-Cuenca, J.J.; Zito, G.; Garzon, S.; Caruso, S.; et al. Scoring systems for the evaluation of adnexal masses nature: Current knowledge and clinical applications. J. Obstet. Gynaecol. 2021, 41, 340-347. [CrossRef] [PubMed]

64. Terzic, M.; Rapisarda, A.M.C.; Della Corte, L.; Manchanda, R.; Aimagambetova, G.; Norton, M.; Garzon, S.; Riemma, G.; King, C.R.; Chiofalo, B.; et al. Diagnostic work-up in paediatric and adolescent patients with adnexal masses: An evidence-based approach. J. Obstet. Gynaecol. 2021, 41, 503-515. [CrossRef]

65. Giudice, L.C. Clinical practice. Endometriosis. N. Engl. J. Med. 2010, 362, 2389-2398. [CrossRef] 
66. DiVasta, A.D.; Vitonis, A.F.; Laufer, M.R.; Missmer, S.A. Spectrum of symptoms in women diagnosed with endometriosis during adolescence vs adulthood. Am. J. Obstet. Gynecol. 2018, 218, 324.e1-324.e11. [CrossRef]

67. D'Alterio, M.N.; Saponara, S.; D'Ancona, G.; Russo, M.; Laganà, A.S.; Sorrentino, F.; Nappi, L.; Angioni, S. Role of surgical treatment in endometriosis. Minerva Obstet. Gynecol. 2021, 73, 317-332. [CrossRef]

68. Chapron, C.; Santulli, P.; De Ziegler, D.; Noel, J.-C.; Anaf, V.; Streuli, I.; Foulot, H.; Souza, C.; Borghese, B. Ovarian endometrioma: Severe pelvic pain is associated with deeply infiltrating endometriosis. Hum. Reprod. 2012, 27, 702-711. [CrossRef]

69. Tanbo, T.; Fedorcsak, P. Endometriosis-associated infertility: Aspects of pathophysiological mechanisms and treatment options. Acta Obstet. Gynecol. Scand. 2017, 96, 659-667. [CrossRef] [PubMed]

70. Terzic, M.; Dotlic, J.; Brndusic, N.; Likic, I.; Andrijasevic, S.; Arsenovic, N.; Ladjevic, N.; Maričić, S. Histopathological diagnoses of adnexal masses: Which parameters are relevant in preoperative assessment? Ginekol. Polska 2013, 84, 700-708. [CrossRef]

71. Terzic, M.; Dotlic, J.; Likic, I.; Nikolic, B.; Brndusic, N.; Pilic, I.; Bila, J.; Maricic, S.; Arsenovic, N. Diagnostic value of serum tumor markers evaluation for adnexal masses. Open Med. 2014, 9, 210-216. [CrossRef]

72. Bazot, M.; Daraï, E. Diagnosis of deep endometriosis: Clinical examination, ultrasonography, magnetic resonance imaging, and other techniques. Fertil. Steril. 2017, 108, 886-894. [CrossRef]

73. Scioscia, M.; Virgilio, B.A.; Laganà, A.S.; Bernardini, T.; Fattizzi, N.; Neri, M.; Guerriero, S. Differential Diagnosis of Endometriosis by Ultrasound: A Rising Challenge. Diagnostics 2020, 10, 848. [CrossRef]

74. Djokovic, D.; Pinto, A.P.; van Herendael, B.J.; Laganà, A.S.; Thomas, V.; Keckstein, J. Structured report for dynamic ultrasonography in patients with suspected or known endometriosis: Recommendations of the International Society for Gynecologic Endoscopy (ISGE). Eur. J. Obstet. Gynecol. Reprod. Biol. 2021, 263, 252-260. [CrossRef] [PubMed]

75. Barra, F.; Biscaldi, E.; Scala, C.; Laganà, A.S.; Vellone, V.G.; Stabilini, C.; Ghezzi, F.; Ferrero, S. A Prospective Study Comparing Three-Dimensional Rectal Water Contrast Transvaginal Ultrasonography and Computed Tomographic Colonography in the Diagnosis of Rectosigmoid Endometriosis. Diagnostics 2020, 10, 252. [CrossRef] [PubMed]

76. Noventa, M.; Scioscia, M.; Schincariol, M.; Cavallin, F.; Pontrelli, G.; Virgilio, B.; Vitale, S.G.; Laganà, A.S.; Dessole, F.; Cosmi, E.; et al. Imaging Modalities for Diagnosis of Deep Pelvic Endometriosis: Comparison between Trans-Vaginal Sonography, Rectal Endoscopy Sonography and Magnetic Resonance Imaging. A Head-to-Head Meta-Analysis. Diagnostics 2019, 9, 225. [CrossRef]

77. Nisenblat, V.; Bossuyt, P.M.M.; Farquhar, C.; Johnson, N.; Hull, M.L. Imaging modalities for the non-invasive diagnosis of endometriosis. Cochrane Database Syst. Rev. 2016, 2, CD009591. [CrossRef] [PubMed]

78. Raglan, O.; Kalliala, I.; Markozannes, G.; Cividini, S.; Gunter, M.J.; Nautiyal, J.; Gabra, H.; Paraskevaidis, E.; Martin-Hirsch, P.; Tsilidis, K.K.; et al. Risk factors for endometrial cancer: An umbrella review of the literature. Int. J. Cancer 2019, 145, 1719-1730. [CrossRef]

79. Terzic, M.; Norton, M.; Terzic, S.; Bapayeva, G.; Aimagambetova, G. Fertility preservation in endometrial cancer patients: Options, challenges and perspectives. Ecancermedicalscience 2020, 14, 1030. [CrossRef]

80. Lortet-Tieulent, J.; Ferlay, J.; Bray, F.; Jemal, A. International Patterns and Trends in Endometrial Cancer Incidence, 1978-2013. J. Natl. Cancer Inst. 2017, 110, 354-361. [CrossRef]

81. Moore, K.; Brewer, M.A. Endometrial Cancer: Is This a New Disease? Am. Soc. Clin. Oncol. Educ. Book 2017, 37, 435-442. [CrossRef]

82. American Cancer Society. Facts E Figures 2021; American Cancer Society: Atlanta, GA, USA, 2021; Available online: https: / / www.cancer.org/cancer/endometrial-cancer.html (accessed on 2 July 2021).

83. Urick, M.E.; Bell, D.W. Clinical actionability of molecular targets in endometrial cancer. Nat. Rev. Cancer 2019, 19, 510-521. [CrossRef]

84. Terzic, M.; Aimagambetova, G.; Terzic, S.; Norton, M.; Bapayeva, G.; Garzon, S. Current role of Pipelle endometrial sampling in early diagnosis of endometrial cancer. Transl. Cancer Res. 2020, 9, 7716-7724. [CrossRef]

85. Braun, M.M.; Overbeek-Wager, E.A.; Grumbo, R.J. Diagnosis and Management of Endometrial Cancer. Am. Fam. Phys. 2016, 93, 468-474.

86. Vitale, S.G.; Capriglione, S.; Zito, G.; Lopez, S.; Gulino, F.A.; Di Guardo, F.; Vitagliano, A.; Noventa, M.; La Rosa, V.L.; Sapia, F.; et al. Management of endometrial, ovarian and cervical cancer in the elderly: Current approach to a challenging condition. Arch. Gynecol. Obstet. 2018, 299, 299-315. [CrossRef]

87. Howlader, N.N.A.K.M.; Noone, A.M.; Krapcho, M.; Garshell, J.; Miller, D.; Altekruse, S.F.; Kosary, C.L.; Yu, M.; Ruhl, J.; Tatalovich, Z.; et al. SEER Cancer Statistics Review, 1975-2015; National Cancer Institute: Bethesda, MD, USA, 2015. Available online: https:/ / seer.cancer.gov/csr/1975_2015/ (accessed on 2 July 2021).

88. Lu, K.H.; Broaddus, R.R. Endometrial Cancer. New Engl. J. Med. 2020, 383, 2053-2064. [CrossRef] [PubMed]

89. Benati, M.; Montagnana, M.; Danese, E.; Mazzon, M.; Paviati, E.; Garzon, S.; Laganà, A.S.; Casarin, J.; Giudici, S.; Raffaelli, R.; et al. Aberrant Telomere Length in Circulating Cell-Free DNA as Possible Blood Biomarker with High Diagnostic Performance in Endometrial Cancer. Pathol. Oncol. Res. 2020, 26, 2281-2289. [CrossRef]

90. Passarello, K.; Kurian, S.; Villanueva, V. Endometrial Cancer: An Overview of Pathophysiology, Management, and Care. Semin. Oncol. Nurs. 2019, 35, 157-165. [CrossRef]

91. Chiofalo, B.; Mazzon, I.; Antonio, S.D.A.; Amadore, D.; Vizza, E.; Laganà, A.S.; Vocaturo, G.; Calagna, G.; Favilli, A.; Palmara, V.; et al. Hysteroscopic Evaluation of Endometrial Changes in Breast Cancer Women with or without Hormone Therapies: Results from a Large Multicenter Cohort Study. J. Minim. Invasive Gynecol. 2020, 27, 832-839. [CrossRef] [PubMed] 
92. Lindemann, K.; Vatten, L.J.; Ellstrøm-Engh, M.; Eskild, A. Body mass, diabetes and smoking, and endometrial cancer risk: A follow-up study. Br. J. Cancer 2008, 98, 1582-1585. [CrossRef] [PubMed]

93. Njoku, K.; Campbell, A.; Geary, B.; MacKintosh, M.; Derbyshire, A.; Kitson, S.; Sivalingam, V.; Pierce, A.; Whetton, A.; Crosbie, E. Metabolomic Biomarkers for the Detection of Obesity-Driven Endometrial Cancer. Cancers 2021, 13, 718. [CrossRef]

94. Renehan, A.G.; Tyson, M.; Egger, M.; Heller, R.F.; Zwahlen, M. Body-mass index and incidence of cancer: A systematic review and meta-analysis of prospective observational studies. Lancet 2008, 371, 569-578. [CrossRef]

95. Kalliala, I.; Markozannes, G.; Gunter, M.J.; Paraskevaidis, E.; Gabra, H.; Mitra, A.; Terzidou, V.; Bennett, P.; Martin-Hirsch, P.; Tsilidis, K.K.; et al. Obesity and gynaecological and obstetric conditions: Umbrella review of the literature. BMJ 2017, 359 , j4511. [CrossRef] [PubMed]

96. Kyrgiou, M.; Kalliala, I.; Markozannes, G.; Gunter, M.J.; Paraskevaidis, E.; Gabra, H.; Martin-Hirsch, P.; Tsilidis, K.K. Adiposity and cancer at major anatomical sites: Umbrella review of the literature. BMJ 2017, 356, j477. [CrossRef]

97. Tsilidis, K.K.; Kasimis, J.C.; Lopez, D.S.; E Ntzani, E.; Ioannidis, J.P.A. Type 2 diabetes and cancer: Umbrella review of metaanalyses of observational studies. BMJ 2015, 350, g7607. [CrossRef] [PubMed]

98. Nead, K.T.; Sharp, S.J.; Thompson, D.J.; Painter, J.N.; Savage, D.B.; Semple, R.; Barker, A.; Perry, J.R.B.; Attia, J.; Dunning, A.M.; et al. Evidence of a Causal Association Between Insulinemia and Endometrial Cancer: A Mendelian Randomization Analysis. J. Natl. Cancer Inst. 2015, 107, 178. [CrossRef] [PubMed]

99. Collaborative Group on Epidemiological Studies on Endometrial Cancer. Endometrial cancer and oral contraceptives: An in-dividual participant meta-analysis of 27,276 women with endometrial cancer from 36 epidemiological studies. Lancet Oncol. 2015, 16, 1061-1070. [CrossRef]

100. Wang, A.; Wang, S.; Zhu, C.; Huang, H.; Wu, L.; Wan, X.; Yang, X.; Zhang, H.; Miao, R.; He, L.; et al. Coffee and cancer risk: A meta-analysis of prospective observational studies. Sci. Rep. 2016, 6, 33711. [CrossRef] [PubMed]

101. Zhou, Q.; Luo, M.-L.; Li, H.; Li, M.; Zhou, J.-G. Coffee consumption and risk of endometrial cancer: A dose-response meta-analysis of prospective cohort studies. Sci. Rep. 2015, 5, 13410. [CrossRef]

102. Al-Zoughool, M.; Dossus, L.; Kaaks, R.; Clavel-Chapelon, F.; Tjønneland, A.; Olsen, A.; Overvad, K.; Boutron-Ruault, M.-C.; Gauthier, E.; Linseisen, J.; et al. Risk of endometrial cancer in relationship to cigarette smoking: Results from the EPIC study. Int. J. Cancer 2007, 121, 2741-2747. [CrossRef] [PubMed]

103. Setiawan, V.W.; Pike, M.C.; Kolonel, L.N.; Nomura, A.M.; Goodman, M.T.; Henderson, B.E. Racial/Ethnic Differences in Endometrial Cancer Risk: The Multiethnic Cohort Study. Am. J. Epidemiol. 2006, 165, 262-270. [CrossRef]

104. Arend, R.C.; Jones, B.A.; Martinez, A.; Goodfellow, P. Endometrial cancer: Molecular markers and management of advanced stage disease. Gynecol. Oncol. 2018, 150, 569-580. [CrossRef] [PubMed]

105. Hutt, S.; Tailor, A.; Ellis, P.; Michael, A.; Butler-Manuel, S.; Chatterjee, J. The role of biomarkers in endometrial cancer and hyperplasia: A literature review. Acta Oncol. 2019, 58, 342-352. [CrossRef] [PubMed]

106. Aimagambetova, G.; Kaiyrlykyzy, A.; Bapayeva, G.; Ukybassova, T.; Kenbayeva, K.; Ibrayimov, B.; Lyasova, A.; Bonaldo, G.; Buzzaccarini, G.; Noventa, M.; et al. Validation of Pipelle endometrial biopsy in patients with abnormal uterine bleeding in Kazakhstani healthcare setting. Clin. Exp. Obstet. Gynecol. 2021, 48, 670-675. [CrossRef]

107. Terzic, M.M.; Aimagambetova, G.; Terzic, S.; Norton, M.; Bapayeva, G.; Garzon, S. Pipelle endometrial sampling success rates in Kazakhstani settings: Results from a prospective cohort analysis. J. Obstet. Gyn. 2021. [CrossRef]

108. Scioscia, M.; Noventa, M.; Laganà, A.S. Abnormal uterine bleeding and the risk of endometrial cancer: Can subendometrial vascular ultrasound be of help to discriminate cancer from adenomyosis? Am. J. Obstet. Gynecol. 2020, 223, 605-606. [CrossRef]

109. Laganà, A.S.; Scioscia, M. Endometrial Cancer in Women with Adenomyosis: An Underestimated Risk? Int. J. Fertil. Steril. 2020, $14,260-261$.

110. Stachowicz, N.; Smoleń, A.; Ciebiera, M.; Łoziński, T.; Poziemski, P.; Borowski, D.; Czekierdowski, A. Risk Assessment of Endometrial Hyperplasia or Endometrial Cancer with Simplified Ultrasound-Based Scoring Systems. Diagnostics 2021, 11, 442. [CrossRef]

111. Will, A.J.; Sanchack, K.E. Endometrial Biopsy. In StatPearls [Internet]; StatPearls Publishing: Treasure Island, FL, USA, 2021.

112. Costas, T.; Belda, R.; Alcazar, J.L. Transvaginal three-dimensional ultrasound for preoperative assessment of myometrial invasion in patients with endometrial cancer: A systematic review and meta-analysis. Med. Ultrason. 2021. [CrossRef]

113. Capozzi, V.A.; Rosati, A.; Rumolo, V.; Ferrari, F.; Gullo, G.; Karaman, E.; Karaaslan, O.; Hacioğlu, L. Novelties of ultrasound imaging for endometrial cancer preoperative workup. Minerva Med. 2021, 112, 3-11. [CrossRef] [PubMed]

114. Zondervan, K.T.; Becker, C.M.; Koga, K.; Missmer, S.A.; Taylor, R.N.; Viganò, P. Endometriosis. Nat. Rev. Dis. Primers 2018, 4, 9. [CrossRef] [PubMed]

115. Zondervan, K.T.; Becker, C.M.; Missmer, S.A. Endometriosis. New Engl. J. Med. 2020, 382, 1244-1256. [CrossRef] [PubMed]

116. Gardner, G.H.; Greene, R.R.; Ranney, B. The histogenesis of endometriosis; recent contributions. Obstet. Gynecol. 1953, 1, 615-637.

117. Simpson, J.L.; Elias, S.; Malinak, L.; Buttram, V.C. Heritable aspects of endometriosis. Am. J. Obstet. Gynecol. 1980, 137, 327-331. [CrossRef]

118. Parasar, P.; Ozcan, P.; Terry, K.L. Endometriosis: Epidemiology, Diagnosis and Clinical Management. Curr. Obstet. Gynecol. Rep. 2017, 6, 34-41. [CrossRef]

119. Frey, G. The Familial Occurrence of Endometriosis. Am. J. Obstet. Gynecol. 1957, 73, 418-421. [CrossRef] 
120. Kennedy, S.; Hadfield, R.; Mardon, H.; Barlow, D. Age of onset of pain symptoms in non-twin sisters concordant for endometriosis. Hum. Reprod. 1996, 11, 403-405. [CrossRef] [PubMed]

121. A Treloar, S.; O'Connor, D.T.; O'Connor, V.M.; Martin, N. Genetic influences on endometriosis in an Australian twin sample. Fertil. Steril. 1999, 71, 701-710. [CrossRef]

122. Stefansson, H.; Geirsson, R.; Steinthorsdottir, V.; Jonsson, H.; Manolescu, A.; Kong, A.; Ingadottir, G.; Gulcher, J. Genetic factors contribute to the risk of developing endometriosis. Hum. Reprod. 2002, 17, 555-559. [CrossRef] [PubMed]

123. Treloar, S.A.; Wicks, J.; Nyholt, D.; Montgomery, G.; Bahlo, M.; Smith, V.; Dawson, G.; Mackay, I.J.; Weeks, D.; Bennett, S.T.; et al. Genomewide Linkage Study in 1,176 Affected Sister Pair Families Identifies a Significant Susceptibility Locus for Endometriosis on Chromosome 10q26. Am. J. Hum. Genet. 2005, 77, 365-376. [CrossRef] [PubMed]

124. Zondervan, K.T.; Treloar, S.A.; Lin, J.; Weeks, D.; Nyholt, D.; Mangion, J.; Mackay, I.J.; Cardon, L.R.; Martin, N.; Kennedy, S.H.; et al. Significant evidence of one or more susceptibility loci for endometriosis with near-Mendelian inheritance on chromosome 7p13-15. Hum. Reprod. 2007, 22, 717-728. [CrossRef]

125. Daftary, G.S.; Taylor, H.S. EMX2 Gene Expression in the Female Reproductive Tract and Aberrant Expression in the Endometrium of Patients with Endometriosis. J. Clin. Endocrinol. Metab. 2004, 89, 2390-2396. [CrossRef]

126. Du, H.; Taylor, H.S. Molecular Regulation of Müllerian Development by Hox Genes. Ann. N. Y. Acad. Sci. 2004, 1034, 152-165. [CrossRef] [PubMed]

127. Dinulescu, D.M.; A Ince, T.; Quade, B.J.; A Shafer, S.; Crowley, D.; Jacks, T. Role of K-ras and Pten in the development of mouse models of endometriosis and endometrioid ovarian cancer. Nat. Med. 2005, 11, 63-70. [CrossRef]

128. Mutter, G.L.; Lin, M.-C.; Fitzgerald, J.T.; Kum, J.B.; Baak, J.P.A.; Lees, J.A.; Weng, L.-P.; Eng, C. Altered PTEN Expression as a Diagnostic Marker for the Earliest Endometrial Precancers. J. Natl. Cancer Inst. 2000, 92, 924-930. [CrossRef] [PubMed]

129. Maxwell, G.L.; I Risinger, J.; Gumbs, C.; Shaw, H.; Bentley, R.C.; Barrett, J.C.; Berchuck, A.; A Futreal, P. Mutation of the PTEN tumor suppressor gene in endometrial hyperplasias. Cancer Res. 1998, 58, 2500-2503.

130. Martini, M.; Ciccarone, M.; Garganese, G.; Maggiore, C.; Evangelista, A.; Rahimi, S.; Zannoni, G.; Vittori, G.; Larocca, L.M. Possible involvement ofhMLH1, p16INK4a andPTEN in the malignant transformation of endometriosis. Int. J. Cancer 2002, 102, 398-406. [CrossRef]

131. Treloar, S.A.; Zhao, Z.Z.; Le, L.; Zondervan, K.; Martin, N.; Kennedy, S.; Nyholt, D.; Montgomery, G. Variants in EMX2 and PTEN do not contribute to risk of endometriosis. Mol. Hum. Reprod. 2007, 13, 587-594. [CrossRef] [PubMed]

132. Painter, J.N.; Nyholt, D.; Morris, A.; Zhao, Z.Z.; Henders, A.; Lambert, A.; Wallace, L.; Martin, N.; Kennedy, S.H.; Treloar, S.A.; et al. High-density fine-mapping of a chromosome 10q26 linkage peak suggests association between endometriosis and variants close to CYP2C19. Fertil. Steril. 2011, 95, 2236-2240. [CrossRef]

133. Painter, J.N.; Nyholt, D.R.; Krause, L.; Zhao, Z.Z.; Chapman, B.; Zhang, C.; Medland, S.; Martin, N.G.; Kennedy, S.; Treloar, S.; et al. Common variants in the CYP2C19 gene are associated with susceptibility to endometriosis. Fertil. Steril. 2014, 102, 496-502. [CrossRef]

134. Zanger, U.M.; Schwab, M. Cytochrome P450 enzymes in drug metabolism: Regulation of gene expression, enzyme activities, and impact of genetic variation. Pharmacol. Ther. 2013, 138, 103-141. [CrossRef]

135. Lee, A.J.; Cai, M.X.; Thomas, P.E.; Conney, A.H.; Zhu, B.T. Characterization of the Oxidative Metabolites of $17 \beta$-Estradiol and Estrone Formed by 15 Selectively Expressed Human Cytochrome P450 Isoforms. Endocrinology 2003, 144, 3382-3398. [CrossRef]

136. Painter, J.N.; Anderson, C.A.; Nyholt, D.; MacGregor, S.; Lin, J.; Lee, S.H.; Lambert, A.; Zhao, Z.Z.; Roseman, F.; Guo, Q.; et al. Genome-wide association study identifies a locus at 7p15.2 associated with endometriosis. Nat. Genet. 2010, 43, 51-54. [CrossRef] [PubMed]

137. Nyholt, D.R.; Low, S.-K.; Anderson, C.A.; Painter, J.N.; Uno, S.; Morris, A.P.; MacGregor, S.; Gordon, S.D.; Henders, A.; Martin, N.; et al. Genome-wide association meta-analysis identifies new endometriosis risk loci. Nat. Genet. 2012, 44, 1355-1359. [CrossRef] [PubMed]

138. Uno, S.; Zembutsu, H.; Hirasawa, A.; Takahashi, A.; Kubo, M.; Akahane, T.; Aoki, D.; Kamatani, N.; Hirata, K.; Nakamura, Y. A genome-wide association study identifies genetic variants in the CDKN2BAS locus associated with endometriosis in Japanese. Nat. Genet. 2010, 42, 707-710. [CrossRef] [PubMed]

139. Adachi, S.; Tajima, A.; Quan, J.; Haino, K.; Yoshihara, K.; Masuzaki, H.; Katabuchi, H.; Ikuma, K.; Suginami, H.; Nishida, N.; et al. Meta-analysis of genome-wide association scans for genetic susceptibility to endometriosis in Japanese population. J. Hum. Genet. 2010, 55, 816-821. [CrossRef] [PubMed]

140. Albertsen, H.M.; Chettier, R.; Farrington, P.; Ward, K. Genome-Wide Association Study Link Novel Loci to Endometriosis. PLoS ONE 2013, 8, e58257. [CrossRef]

141. Uimari, O.; Rahmioglu, N.; Nyholt, D.; Vincent, K.; Missmer, S.A.; Becker, C.; Morris, A.P.; Montgomery, G.; Zondervan, K.T. Genome-wide genetic analyses highlight mitogen-activated protein kinase (MAPK) signaling in the pathogenesis of endometriosis. Hum. Reprod. 2017, 32, 780-793. [CrossRef] [PubMed]

142. Sapkota, Y.; De Vivo, I.; Steinthorsdottir, V.; Fassbender, A.; Bowdler, L.; Buring, J.E.; Edwards, T.L.; Jones, S.; Dorien, O.; Peterse, D.; et al. Analysis of potential protein-modifying variants in 9000 endometriosis patients and 150,000 controls of European ancestry. Sci. Rep. 2017, 7, 11380. [CrossRef] [PubMed]

143. Sapkota, Y.; Fassbender, A.; Bowdler, L.; Fung, J.N.T.; Peterse, D.O.D.; Montgomery, G.; Nyholt, D.; D’Hooghe, T.M. Independent Replication and Meta-Analysis for Endometriosis Risk Loci. Twin Res. Hum. Genet. 2015, 18, 518-525. [CrossRef] 
144. Sapkota, Y.; Steinthorsdottir, V.; Morris, A.P.; Fassbender, A.; Rahmioglu, N.; De Vivo, I.; Buring, J.E.; Zhang, F.; Edwards, T.L.; Jones, S.; et al. Meta-analysis identifies five novel loci associated with endometriosis highlighting key genes involved in hormone metabolism. Nat. Commun. 2017, 8, 15539. [CrossRef] [PubMed]

145. Rahmioglu, N.; Missmer, S.A.; Montgomery, G.W.; Zondervan, K.T. Insights into Assessing the Genetics of Endometriosis. Curr. Obstet. Gynecol. Rep. 2012, 1, 124-137. [CrossRef] [PubMed]

146. Rahmioglu, N.; Montgomery, G.; Zondervan, K. Genetics of Endometriosis. Women's Health 2015, 11, 577-586. [CrossRef] [PubMed]

147. Neto, J.S.; Kho, R.M.; Siufi, D.F.D.S.; Baracat, E.C.; Anderson, K.S.; Abrão, M.S. Cellular, Histologic, and Molecular Changes Associated with Endometriosis and Ovarian Cancer. J. Minim. Invasive Gynecol. 2014, 21, 55-63. [CrossRef]

148. Wiegand, K.C.; Shah, S.P.; Al-Agha, O.M.; Zhao, Y.; Tse, K.; Zeng, T.; Senz, J.; McConechy, M.K.; Anglesio, M.S.; Kalloger, S.E.; et al. ARID1AMutations in Endometriosis-Associated Ovarian Carcinomas. N. Engl. J. Med. 2010, 363, 1532-1543. [CrossRef]

149. Melin, A.; Sparén, P.; Persson, I.; Bergqvist, A. Endometriosis and the risk of cancer with special emphasis on ovarian cancer. Hum. Reprod. 2006, 21, 1237-1242. [CrossRef] [PubMed]

150. Anglesio, M.S.; Papadopoulos, N.; Ayhan, A.; Nazeran, T.M.; Noë, M.; Horlings, H.M.; Lum, A.; Jones, S.; Senz, J.; Seckin, T.; et al. Cancer-Associated Mutations in Endometriosis without Cancer. N. Engl. J. Med. 2017, 376, 1835-1848. [CrossRef]

151. Suda, K.; Nakaoka, H.; Yoshihara, K.; Ishiguro, T.; Tamura, R.; Mori, Y.; Yamawaki, K.; Adachi, S.; Takahashi, T.; Kase, H.; et al. Clonal Expansion and Diversification of Cancer-Associated Mutations in Endometriosis and Normal Endometrium. Cell Rep. 2018, 24, 1777-1789. [CrossRef] [PubMed]

152. Noë, M.; Ayhan, A.; Wang, T.-L.; Shih, I.-M. Independent development of endometrial epithelium and stroma within the same endometriosis. J. Pathol. 2018, 245, 265-269. [CrossRef]

153. Rathore, N.; Kriplani, A.; Yadav, R.K.; Jaiswal, U.; Netam, R. Distinct peritoneal fluid ghrelin and leptin in infertile women with endometriosis and their correlation with interleukin-6 and vascular endothelial growth factor. Gynecol. Endocrinol. 2014, 30, 671-675. [CrossRef]

154. Martincorena, I.; Campbell, P.J. Somatic mutation in cancer and normal cells. Science 2015, 349, 1483-1489. [CrossRef] [PubMed]

155. Moore, L.; Leongamornlert, D.; Coorens, T.H.H.; Sanders, M.A.; Ellis, P.; Dentro, S.C.; Dawson, K.J.; Butler, T.; Rahbari, R.; Mitchell, T.J.; et al. The mutational landscape of normal human endometrial epithelium. Nat. Cell Biol. 2020, 580, 640-646. [CrossRef] [PubMed]

156. Pon, J.R.; Marra, M.A. Driver and Passenger Mutations in Cancer. Annu. Rev. Pathol. Mech. Dis. 2015, 10, 25-50. [CrossRef] [PubMed]

157. Leyendecker, G.; Herbertz, M.; Kunz, G.; Mall, G. Endometriosis results from the dislocation of basal endometrium. Hum. Reprod. 2002, 17, 2725-2736. [CrossRef] [PubMed]

158. Králíčková, M.; Laganà, A.S.; Ghezzi, F.; Vetvicka, V. Endometriosis and risk of ovarian cancer: What do we know? Arch. Gynecol. Obstet. 2019, 301, 1-10. [CrossRef] [PubMed]

159. Alderman, M.H.; Yoder, N.; Taylor, H.S. The Systemic Effects of Endometriosis. Semin. Reprod. Med. 2017, 35, 263-270. [CrossRef]

160. Kajiyama, H.; Suzuki, S.; Yoshihara, M.; Tamauchi, S.; Yoshikawa, N.; Niimi, K.; Shibata, K.; Kikkawa, F. Endometriosis and cancer. Free. Radic. Biol. Med. 2019, 133, 186-192. [CrossRef]

161. Vargas-Hernández, V.M. La endometriosis como factor de riesgo para cáncer de ovario. Cirugía Cirujanos 2013, 81, 163-168. (in Spanish)

162. Saavalainen, L.; Lassus, H.; But, A.; Tiitinen, A.; Härkki, P.; Gissler, M.; Pukkala, E.; Heikinheimo, O. Risk of Gynecologic Cancer According to the Type of Endometriosis. Obstet. Gynecol. 2018, 131, 1095-1102. [CrossRef]

163. Poole, E.M.; Lin, W.T.; Kvaskoff, M.; De Vivo, I.; Terry, K.L.; Missmer, S.A. Endometriosis and risk of ovarian and endometrial cancers in a large prospective cohort of U.S. nurses. Cancer Causes Control. 2017, 28, 437-445. [CrossRef]

164. Rowlands, I.J.; Nagle, C.M.; Spurdle, A.B.; Webb, P.M. Gynecological conditions and the risk of endometrial cancer. Gynecol. Oncol. 2011, 123, 537-541. [CrossRef]

165. Kalaitzopoulos, D.R.; Mitsopoulou, A.; Iliopoulou, S.M.; Daniilidis, A.; Samartzis, E.P.; Economopoulos, K.P. Association between endometriosis and gynecological cancers: A critical review of the literature. Arch. Gynecol. Obstet. 2020, 301, 355-367. [CrossRef]

166. Chen, J.-J.; Xiao, Z.-J.; Meng, X.; Wang, Y.; Yu, M.K.; Huang, W.Q.; Sun, X.; Chen, H.; Duan, Y.-G.; Jiang, C.; et al. MRP4 sustains Wnt/ $\beta$-catenin signaling for pregnancy, endometriosis and endometrial cancer. Theranostics 2019, 9, 5049-5064. [CrossRef]

167. Johnatty, S.E.; Stewart, C.J.R.; Smith, D.; Nguyen, A.; Dwyer, J.O.; O’Mara, T.A.; Webb, P.M.; Spurdle, A.B. Co-existence of leiomyomas, adenomyosis and endometriosis in women with endometrial cancer. Sci. Rep. 2020, 10, 3621. [CrossRef] [PubMed]

168. Mogensen, J.B.; Kjaer, S.K.; Mellemkjaer, L.; Jensen, A. Endometriosis and risks for ovarian, endometrial and breast cancers: A nationwide cohort study. Gynecol. Oncol. 2016, 143, 87-92. [CrossRef] [PubMed]

169. Yu, H.-C.; Lin, C.-Y.; Chang, W.-C.; Shen, B.-J.; Chang, W.-P.; Chuang, C.-M. Increased association between endo-metriosis and endometrial cancer: A nationwide population-based retrospective cohort study. Int. J. Gynecol. Cancer 2015, 25, 447-452. [CrossRef]

170. Franchi, M.; Garzon, S.; Zorzato, P.C.; Laganà, A.S.; Casarin, J.; Locantore, L.; Raffaelli, R.; Ghezzi, F. PET-CT scan in the preoperative workup of early stage intermediate- and high-risk endometrial cancer. Minim. Invasive Ther. Allied Technol. 2019, 29, 232-239. [CrossRef] [PubMed] 
171. Cignini, P.; Vitale, S.G.; Laganà, A.S.; Biondi, A.; La Rosa, V.L.; Cutillo, G. Preoperative work-up for definition of lymph node risk involvement in early stage endometrial cancer: 5-year follow-up. Updates Surg. 2017, 69, 75-82. [CrossRef]

172. Vitale, S.G.; Rossetti, D.; Tropea, A.; Biondi, A.; Laganà, A.S. Fertility sparing surgery for stage IA type I and G2 endometrial cancer in reproductive-aged patients: Evidence-based approach and future perspectives. Updates Surg. 2017, 69, 29-34. [CrossRef]

173. Casarin, J.; Bogani, G.; Piovano, E.; Falcone, F.; Ferrari, F.; Odicino, F.; Puppo, A.; Bonfiglio, F.; Donadello, N.; Pinelli, C.; et al Survival implication of lymphadenectomy in patients surgically treated for apparent early-stage uterine serous carcinoma. $J$. Gynecol. Oncol. 2020, 31, e64. [CrossRef]

174. Freytag, D.; Pape, J.; Dhanawat, J.; Günther, V.; Maass, N.; Gitas, G.; Laganà, A.S.; Allahqoli, L.; Meinhold-Heerlein, I.; Moawad, G.N.; et al. Challenges Posed by Embryonic and Anatomical Factors in Systematic Lymphadenectomy for Endometrial Cancer. $J$. Clin. Med. 2020, 9, 4107. [CrossRef]

175. Lee, S.-Y. Tailored Therapy Based on Molecular Characteristics in Endometrial Cancer. BioMed Res. Int. 2021, $2021,2068023$. [CrossRef]

176. Casarin, J.; Bogani, G.; Serati, M.; Pinelli, C.; Laganà, A.S.; Garzon, S.; Raspagliesi, F.; Ghezzi, F. Presence of Glandular Cells at the Preoperative Cervical Cytology and Local Recurrence in Endometrial Cancer. Int. J. Gynecol. Pathol. 2020, 39, 522-528. [CrossRef] [PubMed]

177. Winterhoff, B.; Thomaier, L.; Mullany, S.; Powell, M.A. Molecular characterization of endometrial cancer and therapeutic implications. Curr. Opin. Obstet. Gynecol. 2020, 32, 76-83. [CrossRef]

178. Cancer Genome Atlas Research Network, Kandoth C, Schultz N, et al Integrated genomic characterization of endometrial carcinoma. Nature 2013, 497, 67-73. [CrossRef]

179. Huvila, J.; Pors, J.; Thompson, E.F.; Gilks, C.B. Endometrial carcinoma: Molecular subtypes, precursors and the role of pathology in early diagnosis. J. Pathol. 2021, 253, 355-365. [CrossRef] [PubMed]

180. León-Castillo, A.; De Boer, S.M.; Powell, M.E.; Mileshkin, L.R.; Mackay, H.J.; Leary, A.; Nijman, H.W.; Singh, N.; Pollock, P.M.; Bessette, P.; et al. Molecular Classification of the PORTEC-3 Trial for High-Risk Endometrial Cancer: Impact on Prognosis and Benefit from Adjuvant Therapy. J. Clin. Oncol. 2020, 38, 3388-3397. [CrossRef] [PubMed]

181. McAlpine, J.; Leon-Castillo, A.; Bosse, T. The rise of a novel classification system for endometrial carcinoma; integration of mo-lecular subclasses. J. Pathol. 2018, 244, 538-549. [CrossRef]

182. Carlson, J.; McCluggage, W.G. Reclassifying endometrial carcinomas with a combined morphological and molecular approach. Curr. Opin. Oncol. 2019, 31, 411-419. [CrossRef] [PubMed]

183. Nakamura, M.; Obata, T.; Daikoku, T.; Fujiwara, H. The Association and Significance of p53 in Gynecologic Cancers: The Potential of Targeted Therapy. Int. J. Mol. Sci. 2019, 20, 5482. [CrossRef] [PubMed]

184. Salvesen, H.B.; Haldorsen, I.S.; Trovik, J. Markers for individualised therapy in endometrial carcinoma. Lancet Oncol. 2012, 13, e353-e361. [CrossRef]

185. Alexa, M.; Hasenburg, A.; Battista, M. The TCGA Molecular Classification of Endometrial Cancer and Its Possible Impact on Adjuvant Treatment Decisions. Cancers 2021, 13, 1478. [CrossRef] [PubMed]

186. Menderes, G.; Lopez, S.; Han, C.; Altwerger, G.; Gysler, S.; Varughese, J.; E Schwartz, P.; Santin, A.D. Mechanisms of resistance to HER2-targeted therapies in HER2-amplified uterine serous carcinoma, and strategies to overcome it. Discov. Med. 2018, 26, 39-50. [PubMed]

187. Erickson, B.K.; Zeybek, B.; Santin, A.D.; Fader, A.N. Targeting human epidermal growth factor receptor 2 (HER2) in gynecologic malignancies. Curr. Opin. Obstet. Gynecol. 2020, 32, 57-64. [CrossRef]

188. Ferriss, J.S.; Erickson, B.K.; Shih, I.-M.; Fader, A.N. Uterine serous carcinoma: Key advances and novel treatment approaches. Int. J. Gynecol. Cancer 2021, 31, 1165-1174. [CrossRef] [PubMed]

189. Stelloo, E.; Nout, R.A.; Osse, E.M.; Juergenliemk-Schulz, I.J.; Jobsen, J.J.; Lutgens, L.C.; Van Der Steen-Banasik, E.M.; Nijman, H.W.; Putter, H.; Bosse, T.; et al. Improved Risk Assessment by Integrating Molecular and Clinicopathological Factors in Early-stage Endometrial Cancer-Combined Analysis of the PORTEC Cohorts. Clin. Cancer Res. 2016, 22, 4215-4224. [CrossRef] [PubMed]

190. Talhouk, A.; DeRocher, H.; Schmidt, P.; Leung, S.; Milne, K.; Gilks, C.B.; Anglesio, M.S.; Nelson, B.H.; McAlpine, J.N. Molecular Subtype Not Immune Response Drives Outcomes in Endometrial Carcinoma. Clin. Cancer Res. 2019, 25, 2537-2548. [CrossRef]

191. Reijnen, C.; Küsters-Vandevelde, H.V.; Prinsen, C.F.; Massuger, L.F.; Snijders, M.P.; Kommoss, S.; Brucker, S.Y.; Kwon, J.S.; McAlpine, J.N.; Pijnenborg, J.M. Mismatch repair deficiency as a predictive marker for response to adjuvant radiotherapy in endometrial cancer. Gynecol. Oncol. 2019, 154, 124-130. [CrossRef]

192. Mackay, H.J.; Freixinos, V.R.; Fleming, G.F. Therapeutic Targets and Opportunities in Endometrial Cancer: Update on Endocrine Therapy and Nonimmunotherapy Targeted Options. Am. Soc. Clin. Oncol. Educ. Book 2020, 40, 245-255. [CrossRef]

193. Gómez-Raposo, C.; Salvador, M.M.; Zamora, C.A.; de Santiago, B.G.; Sáenz, E.C. Immune checkpoint inhibitors in endometrial cancer. Crit. Rev. Oncol. 2021, 161, 103306. [CrossRef]

194. Jamieson, A.; Thompson, E.F.; Huvila, J.; Gilks, C.B.; McAlpine, J.N. p53abn Endometrial Cancer: Understanding the most aggressive endometrial cancers in the era of molecular classification. Int. J. Gynecol. Cancer 2021, 31, 907-913. [CrossRef] [PubMed]

195. Nm, A.E.M.; El-Gelany, S. Differential Expression Patterns of PTEN in Cyclic, Hyperplastic and Malignant Endome-trium: Its Relation with ER, PR and Clinicopathological Parameters. J. Egypt. Natl. Cancer Inst. 2009, 21, 323-331.

196. Giono, L.E.; Manfredi, J.J. The p53 tumor suppressor participates in multiple cell cycle checkpoints. J. Cell. Physiol. 2006, 209, 13-20. [CrossRef] [PubMed] 
197. D'Andrilli, G.; Bovicelli, A.; Paggi, M.G.; Giordano, A. New insights in endometrial carcinogenesis. J. Cell. Physiol. 2012, 227, 2842-2846. [CrossRef]

198. Angioli, R.; Miranda, A.; Aloisi, A.; Montera, R.; Capriglione, S.; Nardone, C.D.C.; Terranova, C.; Plotti, F. A critical review on HE4 performance in endometrial cancer: Where are we now? Tumor Biol. 2014, 35, 881-887. [CrossRef] [PubMed]

199. Kemik, P.; Saatli, B.; Yıldırım, N.; Kemik, V.D.; Deveci, B.; Terek, M.C.; Koçtürk, S.; Koyuncuoğlu, M.; Saygılı, U. Diagnostic and prognostic values of preoperative serum levels ofYKL-40, HE-4 and DKK-3 in endometrial cancer. Gynecol. Oncol. 2016, 140, 64-69. [CrossRef] 